\title{
Developments in nutrition for pasture-based cattle and sheep systems in Ireland
}

\author{
J. Patton ${ }^{1, \dagger}$, M. Dineen ${ }^{2}$, T.W.J. Keady ${ }^{3}$, M. McGee ${ }^{4}$, S. Waters ${ }^{4}$ \\ ${ }^{1}$ Teagasc, Grange, Dunsany, Co. Meath, Ireland \\ ${ }^{2}$ Teagasc, Animal and Grassland Research and Innovation Centre, Moorepark, Fermoy, Co. Cork, Ireland \\ ${ }^{3}$ Teagasc, Animal and Grassland Research and Innovation Centre, Mellows Campus, Athenry, Co. Galway, Ireland \\ ${ }^{4}$ Teagasc, Animal and Grassland Research and Innovation Centre, Dunsany, Co. Meath, Ireland
}

Abstract

For ruminant production systems, the requirement to meet specific nutrient targets in the animal's diet must be balanced with the aim of achieving high utilisation of forage in the overall feed budget. A focus of research and extension in an Irish industry context has been to meet these objectives using grazed pasture as the predominant forage source. This has prompted investigation to improve understanding of the components defining forage nutritive value, as well as the management factors affecting its intake and utilisation by animals. Similarly, quantifying the animal performance responses to varying type, rate and timing of dietary supplementation has been an important area of investigation. This review summarises some of the principal outcomes and developments over recent years across beef, sheep and dairy production systems. In addition, ruminant production systems are increasingly challenged to reduce potential environmental impacts by mitigating nutrient and gaseous emissions across their production cycles. Current and emerging research with regard to this issue, and enteric methane production in particular, is discussed.

Keywords

Grazing $\bullet$ nutrient balance $\cdot$ ruminants $\bullet$ supplementation

\section{Introduction}

Conversion of human-indigestible forage fractions to utilisable protein is the key contribution of ruminant production systems to global human food production (Laisse et al., 2018). Increasingly, however, international agri-environmental policy and the evolving preferences of consumers are placing additional technical demands on livestock farmers (Sidali et al., 2016; European Union (EU) Commission Farm to Fork Strategy, 2020). The primary challenges faced by the ruminant production sector in this regard are well documented and encompass minimising nutrient loss to the environment, reducing dependency on human-edible foodstuffs, addressing animal health and welfare considerations and satisfying consumer perceptions regarding sustainable food systems (Peyraud, 2017). These challenges must be met against a backdrop of often low and variable economic margins generated by primary agricultural production (Teagasc, National Farm Survey, 2019).
In Ireland, the agriculture sector has been traditionally dominated by cattle and sheep production enterprises. Pasture-based production models are characteristic, with land for grazing, hay and silage production accounting for $93 \%$ of utilisable agricultural area (Central Statistics Office [CSO], 2020). The evolution within, and interaction between, the various systems has been heavily influenced by EU agricultural policy. For example, the national dairy cow population declined from approximately 1.6 million $(\mathrm{M})$ head at introduction of milk quotas in 1984 to $1.1 \mathrm{M}$ in 2001 , rising again in recent years to 1.6 $\mathrm{M}$ head with removal of milk quotas. On the other hand, the national beef cow population rose from $0.45 \mathrm{M}$ head in 1984 to 1.2 $\mathrm{M}$ in 2001, coincident with both the introduction of coupled payments and the restrictions imposed by milk quotas, and has reduced to $0.95 \mathrm{M}$ in 2020 . The national population of breeding ewes has fluctuated in that time also, from $1.9 \mathrm{M}$ in 1985 , to a peak of 4.8 M in 1993, to a level of $2.8 \mathrm{M}$ in 2020 (CSO, 2020). 
Furthermore, the sectors have diverged somewhat in structure with dairying developing larger-scale, seasonal pasture systems with greater grazing stocking intensities, beef systems having lower stocking intensities across a range of suckler and finishing models and the sheep sector having moderate farm scale with low grazing stocking densities relative to research benchmarks (Teagasc, National Farm Survey, 2019).

Globally, agriculture is estimated to account for $44 \%$ of methane $\left(\mathrm{CH}_{4}\right), 81 \%$ of nitrous oxide $\left(\mathrm{N}_{2} \mathrm{O}\right)$ and $23 \%$ of total greenhouse gas (GHG) emission equivalents (Food and Agriculture Organization of the United Nations, 2020). In the pasture-based production model practised in Ireland, GHG emissions associated with production and transport of imported feeds, slurry handling and cropping are low relative to confinement-type systems (O'Brien et al., 2012). Enteric methane production therefore accounts for a higher proportion of total emissions, and was estimated at $58 \%$ of agriculturederived GHG in Ireland for 2020 (Environmental Protection Agency [EPA], 2021). When expressed per unit of product, the carbon efficiency of dairy production in Ireland, for example, compares well with international counterparts (Kelly et al., 2020). Nonetheless, total emissions have increased by $8 \%$ between 2014 and 2020 (EPA, 2021), reflecting a change in national herd output and structure. This has occurred in the context of a national climate policy in Ireland that has targeted a $20-30 \%$ reduction in GHG emissions from the agriculture sector before 2030 (Department of Environment, Climate Change and Communications, 2021). Clearly, nutritional mitigation of GHG, in efficiency and absolute terms, is a priority issue for the ruminant production systems nationally. At national level, these underlying factors have been important in framing the research themes and priorities for optimising nutrition management for each industry sector. There are a number of core issues that are common to each, including defining the quality of grazed pasture and conserved forages and its effect on animal performance, understanding the factors affecting productivity responses to feed supplements, nutrition effects on product quality, interactions with animal health and the potential for dietary mitigation of nutrient losses and GHG emissions. This paper presents an overview of some key research outcomes from recent years relevant to these themes, with a particular emphasis on pasture-based sheep, beef and dairy systems in Ireland.

\section{Quantifying the nutritive value of pasture}

The nutritive value of pasture is closely related to its digestibility due to the effect of digestibility on net energy concentration and ingestibility (Peyraud \& Delagarde, 2013). Digestibility also affects the amount of ruminal fermentable carbohydrate that is available to support microbial protein synthesis and hence the supply of metabolisable amino acids (AAs; O'Mara et al., 1997). Pasture digestibility can be quite variable with a wide range being reported for the total-tract digestibility (TTD) in pasture-fed lactating dairy cows $(72 \%$ to $84 \%$ organic matter TTD; Morgan \& Stakelum, 1987; Rius et al., 2012; Garry, 2016). Many factors have been demonstrated to affect the digestibility of pasture such as pasture mass (Mambrini \& Peyraud, 1994; Garry et al., 2021), nitrogen (N) fertiliser application (Delagarde et al., 1997; Peyraud et al., 1997), species and cultivar (Smit et al., 2005; Chen et al., 2019; Garry et al., 2020), morphological proportions (Beecher et al., 2015), environmental conditions (Van Soest, 1994) and seasonal variation (Roche et al., 2009b; Douglas et al., 2020). Over the past few decades, to understand and quantify pasture digestibility, Ireland has primarily focussed on the measurement of total-tract organic matter digestibility (OMD) using the in vivo total collection method in sheep and cattle (Morgan \& Stakelum, 1987; O'Mara, 2000). A number of experiments have demonstrated that immature perennial ryegrass (PRG) can be highly digestible (Morgan \& Stakelum, 1987; Beecher et al., 2014, 2018; Garry et al., $2020,2021)$. The inclusion of white clover into PRG swards has been demonstrated to further increase the in vivo OMD of pasture-based diets (Peyraud, 1993; Hurley et al., 2021). This high OMD of immature pasture results in high concentrations of metabolisable or net energy per kg of dry matter (DM) (Bruinenberg et al., 2002; Institut National de Recherche Agronomique [INRA], 2018). Furthermore, the high concentrations of ruminal fermentable carbohydrate within immature pasture can support high microbial protein flows (Younge et al., 2004). Altogether, these attributes can allow high dry matter intake (DMI) and milk production performance to be achieved from pasture-based diets (Buckley et al., 2000). While an accurate measure of TTD can be achieved from the total collection method, an understanding of the ruminal kinetics of digestion and passage and the digestive compartment in which digestion might occur cannot be attained. This reduces our ability to understand mechanisms regulating DMI, the effect of a suboptimal ruminal environment on digestibility (Huhtanen et al., 2006) and the profile of nutrients available for absorption by the ruminant (e.g. volatile fatty acids, AAs from microbial protein). To attain a greater understanding of the site of digestion and nutrient supply in Irish pasture-fed lactating dairy cows, digesta flow studies incorporating duodenal or omasal sampling were performed (O'Mara et al., 1997; Younge et al., 2004; Dineen et al., 2020, 2021a). These studies have highlighted a number of key characteristics in regard to the nutritive value of pasture; immature pasture is highly digestible with the majority of digestion occurring prior to the omasum/ duodenum; extensive ruminal digestion of immature PRG N/ AA occurs suggesting that cows consuming such diets exhibit a large dependence on microbial AA to support metabolisable 
AA supply; measurement of the rumen pool size of cows fed highly digestible immature pasture indicates that rumen distension does not limit DMl; and consumption of immature pasture stimulates high ruminal liquid passage rate which may affect microbial metabolism and protein synthesis.

The use of omasal sampling has been extremely limited in pasture-fed lactating dairy cow experiments when compared with the large body of literature that exists for indoor feeding systems (Broderick et al., 2010; Huhtanen et al., 2010). The omasal sampling technique conveys a number of advantages over duodenal sampling such as less invasive sampling, reduced variability of measurement (Huhtanen et al., 2010) and increased capability of characterising the different sources of AA flows (i.e. feed, endogenous and microbial populations; Ahvenjärvi, 2006). Incorporating the omasal sampling technique into future studies is imperative to strengthen our understanding of the factors governing ruminal digestion and passage kinetics, DMI and milk production performance of pasture-fed lactating dairy cows.

As many factors with endless combinations can affect the digestibility of pasture-based diets, in vivo experiments to describe their effect are neither practical nor cost effective. Therefore, laboratory feed evaluation techniques and mathematical models are used to estimate the supply of energy and AA from a diet. In addition, laboratory analysis to characterise the nutritive value of pasture pre-grazing provides superior management data in comparison to using historical tabulated values (Doughlas et al., 2021). A number of in vivo digestibility trials were conducted in Ireland from 1981 to 1984 to provide data for the evaluation of three in vitro laboratory procedures to predict in vivo digestibility (Morgan \& Stakelum, 1987). The three in vitro procedures (neutral detergent cellulase [Dowman \& Collins, 1982], rumen fluid pepsin [Tilley \& Terry, 1963] and pepsin cellulose [Jones \& Hayward, 1975]) were demonstrated to have moderate accuracy in predicting in vivo OMD when combined with regression equations (Stakelum et al., 1988). Morgan et al. (1989) subsequently modified the neutral detergent cellulose digestibility procedure for use with the "Fibertec" system which has since been routinely used in Ireland to predict in vivo OMD. The regression equation developed by Stakelum et al. (1988) to predict in vivo OMD was recently evaluated. Beecher et al. (2015) using an independent dataset of in vivo OMD found that predictions of OMD from the Morgan et al. (1989) in vitro procedure were significantly different from those of the in vivo measurements. The authors highlighted that a small sample size and the narrow range of in vivo OMD in the independent dataset may have contributed to the poor prediction capability. Garry et al. (2018) expanded the dataset and derived updated regression equations with a moderate capability to predict in vivo OMD, with a similar accuracy to the equation developed by Stakelum et al. (1988).
In a comprehensive evaluation incorporating 177 samples and utilising the pepsin cellulose method (Aufrère et al., 2007), a moderate capability to predict in vivo OMD of fresh grasses and permanent grasslands was also demonstrated $\left(R^{2}=0.78\right.$; root-mean-square error [RMSE] 2.9; INRA, 2018). Altogether, there seems to be little scope to further increase the accuracy and precision of predicting in vivo OMD from the in vitro OMD procedures. This may be due, at least in part, to a number of in vitro OMD procedure limitations such as the use of cellulolytic enzymes, large pore size filtering apparatus and single fermentation time points. Cellulolytic enzymes do not degrade neutral detergent fibre (NDF) as efficiently as rumen microorganisms (Van Soest et al., 1978), large pore size filtering apparatus has been demonstrated to underestimate the recovery of components of the plant cell wall and overestimate digestibility (Udén, 2006; Raffrenato et al., 2018) and finally, a single fermentation time point can reduce the procedures' ability to adequately describe the dynamic and heterogeneous nature of NDF digestibility (Ellis et al., 2005; Huhtanen et al., 2008).

Nousiainen (2004) evaluated the ability of indigestible NDF (iNDF) concentration, measured after $12 \mathrm{~d}$ of in situ fermentation (Huhtanen et al., 2006), to predict in vivo OMD. The author reported a high capability to predict in vivo OMD at the forage specific level $\left(R^{2}=0.89-0.99\right)$. This was recently supported by the findings of Garry et al. (2021) who demonstrated a close relationship among iNDF and in vivo OMD in sheep consuming PRG $\left(R^{2}=0.92\right)$. However, the in situ procedure, like in vivo OMD, is quite laborious involving multiple handling of cannulated cows. Raffrenato et al. (2018) developed an in vitro method utilising rumen fluid, a small pore size filter paper and multiple fermentation time points to generate a comprehensive in vitro description of NDF digestibility. The authors demonstrated a strong relationship among undigested NDF (UNDF; measured after in vitro fermentation for $240 \mathrm{~h})$ and iNDF $\left(R^{2}=0.89\right.$; Raffrenato et al., 2018). This highlights the potential of the in vitro NDF digestibility procedure to increase our ability to predict in vivo OMD of pasture-based diets. Crucially, the procedure can be performed in a commercial laboratory setting and is repeatable and adaptable for routine feed evaluation.

Near-infrared reflectance spectroscopy (NIRS) technology can be utilised to expedite the feed evaluation process. In regard to forage digestibility, NIRS technology has been demonstrated to successfully predict iNDF concentration (Nousiainen et al., 2004; Krizsan et al., 2014). However, these NIRS calibration equations require sample preparation of drying and grinding which are laborious, time consuming and expensive. Murphy (2020) recently demonstrated the capability of NIRS calibration equations, developed from fresh pasture samples, to predict the concentrations of DM and crude protein (CP). While accurate estimations of DM were achieved, further development of the 
$\mathrm{CP}$ calibration models is required in addition to other chemical components such as iNDF/uNDF. Future work should focus on real-time estimation of the nutritive value of pasture-based diets through the development of fresh NIRS calibration models and other rapid technologies such as hyperspectral sensing (Pullanagari et al., 2012).

\section{Developments in nutrition of dairy cows}

The predominant feeding strategy underpinning dairy production systems in Ireland is to maximise utilisation of grazed pasture in the diet of the lactating herd (O'Donovan et al., 2011). This has proven economic (Hanrahan et al., 2018), product quality (Alothman et al., 2019) and environmental (O'Brien et al., 2012) benefits in an Irish context. The typical annual pasture growth pattern in Ireland results in supplementation being most required during the spring (February/March) and autumn (October/November) grazing rotations, which typically coincide with the early postpartum and late lactation periods, respectively.

Pasture utilisation is a systems efficiency metric that encompasses annual pasture growth and feed demand patterns, supplementary feed and milk output, and is positively associated with profitability per unit area. Milk productivity per cow tends to increase profit only if derived from greater pasture utilisation. Indeed, Ramsbottom et al. (2015) concluded that production costs increase by approximately 1.5 times the rate of direct cost of supplementary feed purchase due to associated capital expenses. At the daily operational level, pasture utilisation for the optimal synthesis of milk requires consistent provision of high-digestibility, high leaf content swards, grazed at the optimal growth stage to the correct residual, by cows of a suitable genotype (Hennessy et al., 2020). Hence, the role of feed supplementation within the system has become tactical in nature, being employed to address deficits in pasture supply and quality, or to deliver specific limiting nutrients.

Achieving high levels of pasture intake while balancing feed demand variation due to stocking rate, with the impact of supplement feeding on pasture and total nutrient intake, is a key consideration for dairy grazing systems (McCarthy et al., 2010). Daily intake of pasture is a limited by the combined effects of bite rate, bite mass and number and duration of grazing bouts (Dillon, 2006). This is of course predicated on the provision of a requisite daily DM allowance such that grazing behaviour and animal intake capacity are first-limiting on herbage intake (Bargo et al., 2003). However, the objective of increasing daily pasture intake must be balanced with a requirement to achieve a post-grazing residual that maintains sward quality for subsequent grazing (Stakelum \& Dillon, 2007). In addition, marginal increases in grazing stocking rate may elicit a milk yield response on a per-hectare basis, despite a reduction in individual cow $\mathrm{DMI}$ and milk productivity (McCarthy et al., 2010). The scale of milk responses to such changes in individual feed allowances may be genotype dependent (McCarthy et al., 2007). McDonald et al. (2011) demonstrated that the impact of stocking rate on individual cow DMI and milk productivity resulted in a quadratic effect of stocking rate on dairy farm profitability per unit area.

The sward characteristics that maximise intake may differ with grazing management regime, for example, optimal pregrazing sward height may be lower for continuous versus rotationally grazed swards (Dillon, 2006). Dry matter intake is higher for swards with higher proportion of leaf content and greater OMD (Peyraud \& Delagarde, 2013). Nonetheless, DMI and fat-corrected milk yield of grazing dairy cows is lower than that of cows offered total mixed diet formulated to maximise nutrient density and DMI (Kolver \& Muller, 1998; O'Callaghan et al., 2016). This is due to the physical limitations to intake imposed by grazing, in combination with higher and more variable NDF content in pasture, and lower non-structural carbohydrate content.

Numerous lactating dairy cow studies have characterised the influence of digestibility on variables such as $\mathrm{DMI}$, rumen pool size, rumination and milk production performance (Oba \& Allen, 1999; Cotanch et al., 2014; Zontini et al., 2015). Beecher et al. (2018) demonstrated, in an investigation with sheep, that the in vivo NDF digestibility of PRG was a better predictor of DMI than in vivo OMD. Dineen et al. (2021b) recently highlighted that when a more accurate characterisation of NDF digestibility is combined with the Cornell Net Carbohydrate and Protein System, a greater understanding of the nutrient supply and milk production performance of grazing dairy cows can be achieved. This increased understanding of pasture nutritive value, in regard to rumen turnover, metabolisable energy (ME) supply and post-ruminal AA flows, can aid in the development of future nutritional strategies to increase the efficiency and productivity of pasture-based systems. Such nutritional strategies could include development of improved pasture management practices (O'Donovan et al., 2002), optimisation of concentrate supplementation (Baudracco et al., 2010), selection of superior plant genetics (Lee et al., 2012) and the development of binary or multi-species pastures (McCarthy et al., 2020).

Nutrition of early lactation dairy cows in grazing systems Supply of ME, and not metabolisable protein or specific AAs, is usually first-limiting for milk production in grazing systems (Kolver \& Muller, 1998). This is primarily a function of physical/behavioural limitations to feed intake on highquality pasture, rather than large differences in nutrient density or digestibility per unit of DM (Bargo et al., 2003). Given the positive associations between grazing season 
length and financial performance (Läpple et al., 2012), nutrition research in an Irish context has orientated toward optimising intake and supplementation of pasture diets during extended grazing periods. The early spring period in particular presents the challenge of synchrony between low postpartum intake potential at the animal level and potentially challenging grazing conditions (Kennedy et al., 2011; Patton et al., 2012). A key objective has been to develop strategies that strike a balance between high grass utilisation, support of high milk solids yield derived primarily from pasture intake and promotion of metabolic health of the cow (Dillon, 2006).

To examine the efficacy of pasture as the primary forage source in early lactation, Kennedy et al. (2005) evaluated performance of cows fed pasture plus concentrate (3-4 kg $\mathrm{DM})$ relative to herd-mates offered a total mixed ration (TMR) containing 0.6 of DM as concentrate plus moderate-quality grass silage, and reported similar solids-corrected yield (25.9 vs. $26.6 \mathrm{~kg}$ ) and bodyweight change. No carryover effects were observed while milk protein content was improved through inclusion of pasture in the diet. Differences in concentrate feeding level were offset by superior intake and digestibility of grazed pasture relative to the forage silage component of the TMR. In contrast, O'Neill et al. (2011) showed significantly increased milk volume and total solids yield for a maize/grass silage/concentrate-based TMR relative to pasture for early lactation cows. This output difference resulted from greater daily DMls for the TMR (19.2 kg vs. $14.5 \mathrm{~kg}$ ) at comparable levels of dietary energy density. Differences in the biological performance of pasture and indoor diets are determined by the DMls, nutrient densities and feed conversion efficiencies achieved within each system paradigm (Kolver, 2003). Such differences will ultimately determine the relative economic and environmental impacts for systems-level comparisons (Shalloo et al., 2004; O'Brien et al., 2012).

McEvoy et al. (2008), developing on the concept of optimising intakes in early season grazing scenarios, imposed a range of herbage allowances and concentrate supplementation rates in a factorial design. Early lactation milk production and grass utilisation were optimised where cows were offered $17 \mathrm{~kg}$ DM pasture plus $3 \mathrm{~kg}$ DM concentrate, or 13 $\mathrm{kg}$ DM plus $6 \mathrm{~kg}$ DM concentrate where pasture availability was limited. Negative residual effects on milk solids yield were observed for unsupplemented groups where daily DM allowances resulted in excessive ( $>0.4$ units) body condition score (BCS) loss in early lactation. Ganche et al. (2013) also found a negative impact on milk solids yield and body condition of tightly restricting early postpartum intakes, albeit via differential herbage allowances at similar concentrate feeding rates. It was demonstrated that cows grazing to $2.7 \mathrm{~cm}$ residual heights had reduced intake and milk solids yield versus $3.5 \mathrm{~cm}$ or $4.2 \mathrm{~cm}$, but there was little evidence of carryover effects in the post-treatment period at common post-grazing residuals. While restricting nutrient intake in early lactation evidently curtails milk productivity, reducing grazing pressure in spring can result in progressive decline in sward digestibility, leading to a milk solids yield loss during summer rotations (Stakelum \& Dillon, 2007). The management aims of high intake and sward conditioning for subsequent grazings must therefore be considered in tandem.

\section{Supplement type and composition effects on dairy cow performance}

Within the overall strategy of increasing grazed pasture in the lactating cow, there is a requirement to define the most suitable feed supplement for particular circumstances. The ideal feed supplement will increase intake of a specific limiting nutrient, minimise pasture substitution to elicit an economic response, have low risk of rumen upset and facilitate ease of storage and feeding (Kolver \& Muller, 1998). Principal issues include rate and timing of supplementation, supplement type, production and health responses, effects on nutrient balances and the overall economic response.

The ingestibility or "fill value" of a forage is dictated by its fibre, protein and DM content and its physical properties (Faverdin et al., 2011) Inclusion of forage with higher ingestibility gives reliable milk responses where it replaces a lower-quality feed, for example, where maize silage replaces moderate-quality grass silage (Burke et al., 2007), or indeed where highdigestibility grass silage replaces lower-digestibility silage (Ferris et al., 2001). Maize may confer $\mathrm{N}$-use efficiency (NUE) advantages compared to grass silage as a basal forage supplement (Burke et al., 2007). Milk responses to conserved silage supplements at grazing are usually limited by forage fill value and cow intake capacity however, particularly in scenarios of pasture allowances and quality are not limiting. For example, Morrison \& Patterson (2007) compared maize silage, whole-crop wheat silage and concentrate as supplement options for mid-lactation cows grazing pasture. Concentrate supplementation produced a lower substitution rate and therefore greater total intake response relative to the forage supplements, resulting in superior milk responses; maize silage produced the greatest milk yield response of the forage supplements compared. Burke et al. (2008), on the other hand, found similar milk solids responses to 4 $\mathrm{kg}$ DM concentrate or maize silage in mid-lactation where supplements were offered in a scenario of restricted pasture allowance; the same study showed additional pasture allowance returning similar milk solids responses to either supplement type.

Concentrate feeding twice daily during milking is the predominant means of supplementation in pasture-based systems in Ireland, as it offers the advantages of simplicity 
of delivery, high energy and protein content and lower impact on pasture intake. It also provides a means of balancing macro and trace mineral deficiencies in pasture (Curran et al., 2016). Factors affecting variation in milk yield and body tissue accretion responses to concentrates are numerous and include pasture allowance and digestibility, stage of lactation and rate of supplementation (Bargo et al., 2003). Horan et al. (2005) also established an effect of cow genotype on marginal milk response to concentrate, which varied from approximately 0.5 to $1.1 \mathrm{~kg}$ solids-corrected milk between New Zealand and North American strains of Holstein Friesian, respectively. Milk responses to supplement feeding are governed to a large extent by substitution rate, defined as the differential between unsupplemented pasture intake and supplemented pasture intake, divided by supplement feeding rate. Therefore, while standard cereal-based concentrates may have net energy book values that are sufficient for up to $2 \mathrm{~kg}$ milk production per $\mathrm{kg} \mathrm{DM}$ fed, the milk response rate is inevitably much lower (approximately 1:1) due to pasture substitution and the negative associative effect of concentrate on whole diet digestibility (Noziere et al., 2018). Developing more accurate real-time decision support on the likely responses to supplementation at pasture is an important objective (Ruelle et al., 2015).

Concentrate composition also impacts production and nutrient-use efficiency responses. A key aim for pasture feeding systems has been to reduce $N$ surpluses and therefore urinary $\mathrm{N}$ excretion to the environment. Increasing pasture utilisation, grazing season length and milk solids yield are important factors (Ryan et al., 2012), while moderating CP inclusion levels in supplement can also play a role. On ryegrass diets, provision of a moderate allowance of highenergy, low-protein supplement can improve efficiency of microbial protein synthesis and duodenal AA flow (O'Mara et al., 1997). The $\mathrm{N}$-efficiency effect of moderating supplement protein is dependent on specific composition and herbage $\mathrm{N}$ content. Reid et al. (2015) found no difference in milk solids yield or milk protein content, when pasture was supplemented with $3 \mathrm{~kg}$ DM of concentrate ranging from 90 to $277 \mathrm{~g} / \mathrm{kg}$ DM. Feeding lower CP ration reduced blood urea N levels. Differences in urinary $\mathrm{N}$ excretion were minor across treatments however, which was attributed to high CP levels in the herbage and moderate level of supplementation. Whelan et al. (2012b), operating on lower pasture CP content, recorded a reduction in solids-corrected milk yield when concentrate protein was reduced from 180 to $150 \mathrm{~g} / \mathrm{kg}$ DM. However, the effect was negated by replacing barley with maize meal as a starch source, or by inclusion of a methionine precursor (2-hydroxy-4-methylthio butanoic acid). Both strategies ensured improved supply of AA to the mammary gland despite the reduction in overall $\mathrm{CP}$ content. In that study also, a simple reduction of concentrate CP did not alter urinary $\mathrm{N}$ excretion due to a reduction in milk $\mathrm{N}$, whereas the modified low-protein diets improved $\mathrm{N}$ recovery rate. Burke et al. (2008) reported a reduction in urinary $\mathrm{N}$, for no change in milk output, from feeding a lower CP concentrate (97 vs. $197 \mathrm{~g} / \mathrm{kg} \mathrm{DM}$ ) with restricted pasture allowance. CP content remains widely used as a proxy for feed "quality" in dairy systems at industry level. However, there is significant scope to moderate $\mathrm{N}$ surpluses and lower costs of imported protein, by implementing strategies based on supply of dietary protein digestible in the small intestine (PDI), from pasture diets and supplements.

Choice of energy source for concentrate supplements may also affect milk yield and nutrient efficiency responses on pasture diets. Bargo et al. (2003), summarising studies involving early lactation cows grazing immature ryegrass swards, concluded a positive effect on milk yield by substituting digestible fibre sources (beet pulp, citrus pulp, soya hills) for starch-based energy supplements (barley, wheat). The benefits were less apparent in studies involving swards of lower digestibility however. Whelan et al. (2012a) demonstrated a milk response benefit to maize compared to barley as a concentrate energy source in early lactation grazing cows. In contrast, McKay et al. (2019), using late lactation grazing cows, showed a greater milk production response, and improved NUE, for a barley-based concentrate compared to a maize-based concentrate; pasture substitution was higher for the maize-based concentrate in that study. Higgs et al. (2013) similarly reported higher milk yield but lower milk fat content for starch-based compared to fibrebased concentrate supplements. Collectively, these studies indicate that optimal energy source for pasture supplements is dependent on basal forage quality, stage of lactation and proportion of concentrate offered in the daily diet.

A particular issue for grazing diets is the potential effect of sward type and carbohydrate composition of concentrate supplements on the risk of sub-acute ruminal acidosis (SARA). This disorder is generally defined on the basis of mean rumen $\mathrm{pH}$ with values below 5.8 considered confirmative, and has been associated with reduced milk solids yield, milk fat depression and health issues such as lameness and liver abscesses (Abdela, 2016). The risk of SARA is elevated where diets contain increased levels of non-fibre carbohydrate and reduced structural/forage fibre, which has led to some concerns regarding the potential role of grazing higher digestibility swards. Lewis et al. (2010) examined the effect of pre-grazing herbage mass across a wide practical range $(1,200,1,600$ and 2,200 $\mathrm{kg} \mathrm{DM} / \mathrm{ha})$ and found no significant effect on ruminal $\mathrm{pH}$ however. O'Grady et al. (2008) classified commercial dairy herds for SARA risk based on rumen $\mathrm{pH}$ profiles measured by rumenocentesis. Higher-risk herds were found to be grazing swards with higher acid and NDF contents while there was no difference in milk fat or milk fat to protein ratio between herds classified as high 
or low rumen $\mathrm{pH}$ around threshold of 5.8. Enriquez-Hidalgo et al. (2014) reported higher mean rumen $\mathrm{pH}$ for cows grazing ryegrass-white clover swards compared to ryegrass only swards in autumn, despite lower NDF content in the sward containing clover; no differences were observed during spring and summer periods. In terms of concentrate type at pasture, including greater fractions of digestible fibre and/or more slowly degradable starch at pasture may be beneficial for rumen $\mathrm{pH}$ (Stakelum \& Dillon, 2003); however, consistency of milk production responses can be difficult to quantify given the multiplicity of diet, sward and animal factors involved (Kolver $\&$ de Veth, 2002). Overall, it may be an over-simplification to assume definitive causation between provision of high-quality pasture at optimal pre-grazing mass and the risk of SARA. Further work is warranted to clarify the potential role in milk fat depression of temporal changes in rumen bio-hydrogenation of polyunsaturated fat content (Schroeder et al., 2004), particularly in immature grazed pasture.

\section{Interactions between nutrition status and fertility in} dairy cows

Throughout the 1990s and early 2000s, the issue of declining dairy cow pregnancy rates while milk production per cow increased was widely reported internationally (Lucy, 2001). Mee (2004) quantified this trend in an Irish context as a decline in first-insemination conception rate of approximately 0.9 percentage points per year annually over a $10-y r$ period, and a resultant increase in annual empty culling rates. The economic cost of suboptimal dairy herd fertility includes reduced milk production, culling and replacement costs and veterinary intervention. The cost is exacerbated in pasturebased systems due to the loss of synchrony between pasture supply and herd feed demand (Shalloo et al., 2014); therefore, solutions to impaired dairy cow fertility have been an important research objective in recent decades.

Numerous contributing factors to declining dairy herd fertility have been posited including changes to herd scale and structure, reproductive management protocols and disease/ immunity burdens (Crowe et al., 2018). Antagonism between genetic selection for milk productivity in early lactation and resumption of ovarian function and establishment of pregnancy has emerged as a predominant causal mechanism. More specifically, this has been characterised as being mediated through changes in the severity and duration of early lactation negative energy balance, that is, the differential between dietary nutrient intake and demand, rather than changes milk yield per se (Lucy, 2019).

A more severe dietary energy deficit in early lactation results in a more rapid BCS loss. Many studies have associated such accelerated rates of BCS loss with disimproved fertility outcomes (Buckley et al., 2003; Berry et al., 2003; Roche et al., 2009a). While it is recognised that dairy breeding indices rewarding high milk production at the expense of body tissue mobilisation elicited this trend (Lucy, 2019), various nutritional interventions have been attempted to arrest the impact on fertility. In a pasture system context, these intervention options are effectively constrained to an economically feasible rate and type of supplement fed in addition to pasture; studies investigating the fertility outcomes of changing type and rate of parlour-fed concentrates have predominated as a result. For example, Coleman et al. (2009), in a genotype by supplement rate study, found no difference in conception rate, embryo mortality rate or final pregnancy rate in grazing cohorts offered $3.4 \mathrm{~kg}$ compared to $0.4 \mathrm{~kg}$ DM of starch/fibre-based concentrate through the breeding season. Genetic index for fertility on the other hand delivered marked improvement in fertility metrics. In a similarly designed experiment, Vance et al. (2013) examined the effect of annual concentrate supplementation rate $(530,1,092$ and $1,667 \mathrm{~kg} \mathrm{DM} / \mathrm{cow})$ and genotype (Holstein, Holstein Jersey F1 hybrid) on milk productivity and fertility parameters. Concentrate feeding rate did not impact timing of postpartum resumption of ovarian cyclicity, conception rate or proportion of cows pregnant by end of breeding. In contrast, the Jersey/Holstein hybrid genotype had superior performance to the Holstein genotype across all these metrics; no genotype by feeding system interactions were detected. These trends were consistent with the findings of comparable work by Horan et al. (2004) and point to the limited capacity of simple changes in concentrate supplement rates to correct fertility issues where pasture quality and DM allowance are not limiting.

A further area of potential dietary intervention to improve fertility has been manipulation of the late gestation and peripartum diet, with the objective of creating a smoother transition to lactation and ultimately improved cow health. Strategies investigated have included alteration of pre-partum protein content (Murphy, 1999), inclusion of starch supplementation to condition rumen papillae to lactation diets and/or reduction in dietary energy density across the dry period to limit body tissue accretion (McNamara et al., 2003; Ryan et al., 2003; Butler et al., 2011). The broad conclusion from such studies has been that dairy herd health and fertility will not be compromised where dry period feeding programmes deliver optimal BCS at calving (3.0-3.25); a daily protein (PDI) intake of $610-630 \mathrm{~g}$ in late gestation; and a mineral status (dietary cation-anion balance, $\mathrm{Ca}, \mathrm{P}$ and $\mathrm{Mg}$ content) that minimises (sub) clinical hypocalcaemia at calving. The options to achieve such outcomes are manifold and can generally be achieved using relatively simple grass silage-based dry cow diets (Mulligan et al., 2006).

A key development in thinking around potential for dietary manipulation of fertility has been the demonstration of 
genetic control over peripartum nutrient partitioning and metabolic status, which effectively dictates metabolic status and immune function responses to diet in early lactation. For instance, Dechow et al. (2017) found that cows with a genetic tendency to be thin also had elevated growth hormone, B-hyroxybutyrate and non-esterified fatty acid profiles in early lactation; this had negative impacts on fertility. Moreover, Moore et al. (2014) reported that, on typical pasture-plusconcentrate diets, high economic breeding index (EBI) cows had increased blood insulin, insulin-like growth factor I and glucose levels, and maintained high BCS, compared to low EBI herd-mates. Postpartum uterine health and interval to resumption of ovarian cyclicity were also improved, while yield of milk solids was similar across the genotypes. Using the same animal model, Moran et al. (2016) identified strainmediated differences in expression of key metabolism, fertility and immunity-related genes in liver and muscle tissue across early- and mid-lactation time points; high fertility cows had clear advantages in capacity to favourably partition nutrients to health and fertility functions.

Therefore, while prudent nutritional management is important for establishing the conditions for good herd fertility, it is clear that improved genetic selection for energy balance and reproductive traits has been the primary factor in reversing negative herd performance trends in recent years (Cummins et al., 2012; Berry et al., 2016; Lucy, 2019). This has been delivered through the $\mathrm{EBI}$ in an Irish context; calving rates and milk solids yields have increased simultaneously in the national dairy cow population in line with their inclusion as selection objectives (Ring et al., 2021). Changes to herd breeding values for fertility have facilitated simplified management of energy balance in early lactation.

\section{Developments in nutrition of sheep}

Prime lamb production in Ireland is grass-based with lambing concentrated in March to coincide with grass growth. The mean stocking rate is 7.6 ewes per hectare on lowland farms whilst the mean number of lambs reared per ewe joined is 1.3 (National Farm Survey, 2019). Grass, both grazed and conserved as silage, can account for up to $95 \%$ of total annual DMI in well-managed grass-based systems (Keady \& Hanrahan, 2007).

Systems studies in Ireland have shown that $485-500 \mathrm{~kg}$ of lamb carcass can be produced per hectare from grass-based production models (Keady et al., 2009; Hanrahan, 2010). More recently, from a 12-yr study in which only triplet reared lambs were offered concentrate pre-weaning, and grazing sward height management was as described by Keady (2010). Keady et al. (2018) reported that all lambs were slaughtered (mean carcass weight $19.9 \mathrm{~kg}$ ) prior to the end of the grazing season. To achieve this level of performance, mean daily live weight gains of 386,302 and $275 \mathrm{~g} / \mathrm{d}$, for lambs reared as singles, twins and triplets, respectively, were required. Supplementing a triplet-rearing ewe and her lambs with approximately $90 \mathrm{~kg}$ concentrate resulted in triplet lambs having the same performance as lambs born and reared as twins (Keady et al., 2018).

Each $0.5 \mathrm{~kg}$ increase in lamb birth weight (BW) increases subsequent weaning weight by $1.7 \mathrm{~kg}$ (Keady et al., 2007; Keady \& Hanrahan, 2009a, 2009b, 2018, 2021). Increased BW per se accounts for $53 \%$ of the increase in weaning weight (Keady \& Hanrahan, 2009b). Birth weight also affects lamb mortality and thus the number of lambs reared per ewe joined. For twins and triplets the optimum BW is 0.93 and 0.78 times that of singles (Hanrahan \& Keady, 2013). Each $1 \mathrm{~kg}$ reduction in ewe weight loss between mid-pregnancy and post-lambing reduces lamb mortality by 0.2 percentage units (Keady \& Hanrahan, 2013b).

Lamb BW is influenced by many factors. Grass silage digestibility affects both intake and nutritive value of silage and, consequently, is the most important factor influencing grass silage feed value (FV). Form a review of the literature, Keady et al. (2013a, 2013b) concluded that each $10 \mathrm{~g} / \mathrm{kg}$ increase in digestibility increased lamb BW and ewe weight at lambing by $52.3 \mathrm{~g}$ and $1.3 \mathrm{~kg}$, respectively. Keady \& Hanrahan (2021) reported that the proportional increase in silage intake due to increasing silage FV was similar during mid and late pregnancy, thus increasing the intakes of $\mathrm{ME}$ and digestible undegradable protein (DUP) by $53 \%$ and $28 \%$, respectively. During the final 6 wk of pregnancy, ewes offered high FV grass silage (DM digestibility [DMD] $=788 \mathrm{~g} /$ $\mathrm{kg}$, silage intake potential $=92 \mathrm{~g} / \mathrm{kg}$ W0.75) gained 0.15 units BCS whilst those offered medium FV silage (DMD $=698 \mathrm{~g} / \mathrm{kg}$, silage intake potential $=82 \mathrm{~g} / \mathrm{kg}$ W0.75) lost 0.35 units BCS (Keady \& Hanrahan, 2021). Furthermore, increasing silage FV offered to ewes during mid and late pregnancy improved their progeny weaning weight by $1.9 \mathrm{~kg}$, thus reducing age at slaughter by $16 \mathrm{~d}$.

Whilst chop length has no effect on silage intake, or on the performance of beef cattle (Steen, 1984) or dairy cows (Gordon, 1982), it affects the intake characteristics of silage when offered to pregnant ewes (Chestnutt, 1989) and finishing lambs (Fitzgerald, 1996). Using a precision chop harvester relative to single chopping to reduce chop length increased silage intake and, consequently lamb BW by $0.25 \mathrm{~kg}$ whilst reducing ewe weight loss during pregnancy by $4.9 \mathrm{~kg}$ (Chestnutt, 1989).

Increasing the DM concentration of maize at harvest alters chemical composition of the resulting silage, due to reduced concentrations of acid detergent fibre and $\mathrm{CP}$, and increases starch and ME concentrations (Keady et al., 2003, 2008a, 2013a; Keady \& Hanrahan, 2013b, 2021). Increasing the 
DM of maize at harvest (DM from 180 to $259 \mathrm{~g} / \mathrm{kg}$ ) offered to ewes during mid and late pregnancy increased total DM and ME intakes by $31 \%$ and $43 \%$, respectively, and ewes were $4.2 \mathrm{~kg}$ heavier at lambing and had a significantly higher BCS, but lamb BW was not altered (Keady \& Hanrahan, 2021), indicating partitioning of ME to BCS rather than to foetal growth. However, lambs from ewes that had been offered the silage made from the higher DM maize gained more weight from $5 \mathrm{wk}$ to weaning and were $14 \mathrm{~d}$ younger when drafted for slaughter relative to lambs from ewes that received low DM maize silage (Keady \& Hanrahan, 2021).

The effect on ewe and lamb performance of replacing grass silage with maize silage is influenced by the FV of the grass silage and the maturity of the maize crop at harvest. The intake of ME is increased by replacing medium FV grass silage with maize silage but is reduced when high FV silage is replaced by maize silage (Keady \& Hanrahan, 2021). Previously, Keady et al. (2008a) observed, with dairy cows, that partially $(40 \%)$ replacing medium FV and high FV grass silages with maize silage resulted in total daily DMI increases of 2.25 and $0.51 \mathrm{~kg} / \mathrm{cow}$, respectively. Similarly, Keady et al. (2003) observed that, with grass silages of low (ME 10.2 MJ/ $\mathrm{kg} \mathrm{DM}$ ), medium (ME 11.0 MJ/kg DM) and high (ME 12.0 MJ/ $\mathrm{kg} \mathrm{DM}) \mathrm{FV}$, replacing of $40 \%$ of the grass silage with maize silage resulted in a response in daily total DMI of $+1.85,+1.45$ and $-0.10 \mathrm{~kg} / \mathrm{cow}$, respectively.

The response to concentrate feed level in late pregnancy is dependent on forage FV, and thus a substitution effect. Keady \& Hanrahan (2021) reported substitution rates of 0.18 and $0.75 \mathrm{~kg}$ silage DM per $1 \mathrm{~kg}$ increase in concentrate feed level for medium and high FV silages, respectively. Thus, increasing concentrate feed level from 15 to $25 \mathrm{~kg}$ during the final $6 \mathrm{wk}$ of pregnancy did not increase ewe or lamb performance as the response in ME intake was only $26 \%$ of the response from increasing silage FV (Keady \& Hanrahan, 2021). Previously, it was reported that increasing concentrate feed level from 15 to $25 \mathrm{~kg}$ during late pregnancy improved the BW of lambs born to ewes offered low FV grass silage (DMD $=660 \mathrm{~g} / \mathrm{kg}$ DM) but had no significant effect on BW of lambs from ewes offered high FV grass silage (Keady \& Hanrahan, 2010).

The ingredient composition of concentrate offered to pregnant ewes affects lamb body weight at birth and subsequent growth performance. Keady \& Hanrahan (2012) concluded that replacing rapeseed, maize distillers and maize gluten with soyabean meal as the main protein source in concentrates which were iso-energetic and iso-nitrogenous increased lamb BW by $0.36 \mathrm{~kg}$, equivalent to increasing the feed level of the non-soya-based concentrate by $75 \%$, that is, $16-28 \mathrm{~kg}$ during late pregnancy.

Initial studies (Keady et al., 2007, 2009; Keady \& Hanrahan, 2009a) indicated that, relative to ewes that were housed unshorn and offered silage-based diets, ewes extended grazing (offered set allowances of deferred herbage) produced lambs that were heavier at birth $(0.7 \mathrm{~kg})$ and weaning $(2.4 \mathrm{~kg})$. The effects of extended grazing on lamb BW varied with stage of pregnancy when extended grazing had occurred. Relative to ewes that were housed and unshorn, ewes that were extended grazed during mid (Keady \& Hanrahan, 2009a, Keady et al., 2007), late (Keady et al., 2007) or during both mid and late pregnancy (Keady et al., 2007; Keady \& Hanrahan, 2009a) produced lambs which were $0.18,0.37$ and $0.59 \mathrm{~kg}$ heavier at birth. Ewes that were shorn at housing or extended grazed during mid and late pregnancy produced lambs with similar BWs (Keady \& Hanrahan, 2009a), indicating that the response to extended grazing was attributable to reduced heat stress outdoors rather that any nutritional benefit from extended-grazed herbage which has an FV similar to medium or low FV grass silage (Keady \& Hanrahan, 2007).

\section{Feeding concentrate to lambs at pasture}

The lamb performance response to concentrate supplementation at pasture depends on grass supply and its FV, and on the level of concentrate offered. From the results of four consecutive grazing seasons in set-stocked grazing systems, Grennan \& McNamara (2005) concluded that offering $300 \mathrm{~g}$ concentrate daily to lambs grazing to a low residual sward height $(5 \mathrm{~cm})$ resulted in the same level of lamb performance pre-weaning as that for lambs grazing to a high residual height $(6 \mathrm{~cm})$ without concentrate supplementation. While concentrate supplementation reduced the age to slaughter by $28 \mathrm{~d}$, increasing grass height from $5 \mathrm{~cm}$ to $6 \mathrm{~cm}$ reduced the age at slaughter by $13 \mathrm{~d}$, equivalent to feeding $16.3 \mathrm{~kg}$ concentrate per lamb from birth to slaughter.

Increasing forage FV or concentrate feed level increases dressing proportion (Keady \& Hanrahan, 2013b, 2015) and thus drafting weight, to achieve a given carcass weight, is reduced. Ad libitum concentrate feeding results in the highest level of lamb performance. Keady \& Hanrahan (2013b, 2015) reported daily gains of 267 and $228 \mathrm{~g}$, respectively - which were at least $30 \%$ greater than forage-based diets. Whilst shearing lambs, offered a wide range of dietary treatments, increased intakes of DM and ME, lamb carcass gain was not altered; thus, efficiency of conversion of ME to carcass gain was reduced (Keady \& Hanrahan, 2015). Each $10 \mathrm{~g} / \mathrm{kg}$ increase in silage digestibility increases lamb carcass gain by $9.3 \mathrm{~g} / \mathrm{d}$ (Keady et al., 2013b). As concentrate feed level increases, the response to silage digestibility declines due to the reduction in the proportion of forage in the diet (Keady \& Hanrahan, 2013a, 2013b, 2015). The response to concentrate feed level varies with silage FV and thus substitution rate. Keady \& Hanrahan (2015) reported linear and quadratic growth rate responses to increasing concentrate feed level 
with medium and high FV grass silages, respectively. Previous authors (Steen et al., 2002; Keady et al., 2008b) have shown that increasing silage $\mathrm{FV}$ increases $\mathrm{ME}$ intake and also increases the efficiency of utilisation of ME for carcass gain. The response to replacing grass silage with maize silage depends on the FV of the grass silage (Keady et al., 2003, 2008a, 2008b; Keady, 2005; Keady \& Hanrahan, 2013a, 2013b). For example, replacing medium and high FV grass silage with maize silage altered forage DMI of finishing lambs by $+19 \%$ and $-25 \%$, respectively (Keady \& Hanrahan, 2013a, 2013b).

In a survey of herbage mineral content, $80 \%, 73 \%, 23 \%$ and $11 \%$ of Irish sheep farms were considered to be deficient for $\mathrm{I}, \mathrm{Co}$, Se and $\mathrm{Zn}$, respectively, and the concentrations of $\mathrm{Cu}$, $\mathrm{I}$, Co, Se and $\mathrm{Zn}$ vary by month with highest concentrations generally occurring in the spring and autumn (Hession, 2021). In the case of Se, $89 \%$ of farms were classified as marginal, whilst herbage on all farms met the dietary requirements for Cu. Sixty-nine percent of Irish sheep producers supplement their flocks with minerals and vitamins; drenching and mineral buckets are the most preferred supplementation methods for lambs and ewes, respectively (Hession et al., 2018a). Supplementation with $\mathrm{Co}$, either by drench or bolus, had no effect on ewe BW, litter size, number of lambs reared per ewe joined or on lamb BW at birth or weaning (Hession et al., 2018b). Keady et al. (2017) reported that supplementing lambs with Co post-weaning increased weight gain in a rotational system and reduced the age at drafting for slaughter. Response to mineral supplementation depends on herbage mineral availability and supplementation decisions should be evidence based.

\section{Product quality}

Carcass classification, as set out in EU Regulation 2137/92, is undertaken to improve market transparency. Hanrahan (2006) concluded that as lamb carcass weight increased from $16 \mathrm{~kg}$ to $22 \mathrm{~kg}$, the proportion of intramuscular fat increased from 0.15 to 0.22 , an increase of $50 \%$. Using slaughter data from 250,000 lamb, Hanrahan (2006) concluded that most carcasses fall into three categories, $33.3 \%$ and $63.6 \%$ classified as conformation $U$ and $R$, respectively, while $82.4 \%$ of carcass are assigned fat class 3 . Using these data Hanrahan concluded that carcasses assigned to fat classes 2, 3 and 4 had intramuscular fat levels of $16.7 \%, 23.5 \%$ and $31.2 \%$, respectively. On grass-based systems castrating male lambs reduced lamb weaning weight by $1.8 \mathrm{~kg}$ whilst increasing the age at slaughter by $16 \mathrm{~d}$ (Hanrahan, 1999). On grass-based systems, in which males were slaughtered prior to the end of the grazing season, leaving male lambs entire had no negative impact on meat flavour or eating quality but improved tenderness relative to meat from castrates (Keady et al., 2015).

\section{Developments in nutrition of beef cattle}

Feed is a primary input accounting for over $75 \%$ of direct costs of beef production. Consequently, converting feed into animal product as efficiently as possible is a major determinant of profitability (Taylor et al., 2018) and environmental sustainability (Fitzsimons et al., 2013; Taylor et al., 2020). Seasonality of grass growth dictates that pasture-based beef production systems consist of a grazing season and an indoor winter period annually, with grass silage providing the winter forage on most farms (McGee et al., 2014). Of the predominant feedstuffs available, grazed pasture is cheapest, purchased concentrate is the most expensive and grass silage and other conserved forages are intermediate (Finneran et al., 2012). Costings of annual grass consumed when the grazing and conservation areas are integrated, which is the norm on most beef farms, are much more complex (Finneran et al., 2011). The comparatively lower cost of efficiently produced grazed pasture means that the evolution of pasture-based beef production systems entailed optimising the contribution of high-nutritive value grazed herbage to lifetime intake of feed, and providing grass silage and concentrate as efficiently and at as low a cost as feasible. For example, within spring-calving suckler calf-tobeef research production systems, the composition of the annual feed budget on a DM basis comprises approximately 0.61 grazed grass, 0.31 grass silage and 0.08 supplementary concentrates (McGee et al., 2018b), with high individual and per-hectare animal output. Corresponding values for suckler calf-to-weanling systems are $0.73,0.26$ and 0.01 , respectively. Consequently, these systems predominantly convert "human-inedible" forages into "human-edible" beef meat products.

\section{Growing/finishing cattle at grass}

Grazed grass intake of growing beef cattle grazing PRGbased swards typically ranges from 14.0 to $20.0 \mathrm{~g} / \mathrm{kg}$ live weight across contrasting genotypes (Clarke et al., 2009; Lawrence et al., 2012). Differences in pasture species and grazing management influence the feeding value of herbage offered which, in turn, impacts performance of grazing beef cattle. In well-managed rotationally grazed systems and good grazing conditions, a target daily live weight gain of $1.0 \mathrm{~kg}$ throughout the grazing season should be attainable for steers without concentrate supplementation (Regan et al., 2018); however, in commercial practice this is often not the case. Grazing excessively high or low pre-grazing herbage masses (Doyle et al., 2019, 2021) and grazing too tightly (Doyle et al., 2020; O'Riordan et al., 2011a) negatively impacts beef cattle growth at pasture. 
Subsequent compensatory growth at pasture diminishes the growth advantage of early turnout to pasture in spring of "yearling" cattle compared to their counterparts offered grass silage plus supplementary concentrates and turned out 3-4 wk later (Gould et al., 2011a; McGee et al., 2014). Relatively high growth rates of cattle at pasture are often due to the expression of compensatory growth (McGee et al., 2014). Furthermore, growth rates of cattle at pasture do not necessarily represent the true growth potential of the animals due to the fact that performance is usually considerably lower than that of similar animals finished indoors on highconcentrate diets (Lenehan et al., 2015a).

Grazed grass herbage is characterised by high CP concentrations resulting in imbalances in the supply of carbohydrate and protein in the rumen of beef cattle and inefficiency of $\mathrm{N}$ capture (Owens et al., 2008a), and consequently relatively low NUE (O'Connor et al., 2019). Strategies to reduce urinary $\mathrm{N}$ excretion in grazing beef cattle include reducing fertiliser $\mathrm{N}$ application rate (O'Connor et al., 2019), increasing grass regrowth interval (Owens et al., 2008a) and supplementation with energy sources (O'Connor et al., 2018). Reducing dietary CP is a primary strategy to mitigate $\mathrm{N}$ excretion and related emissions from beef cattle, and may reduce feed costs too.

The potential benefits of binary grass-clover (legume) swards compared to grass monocultures, in terms of herbage nutritive value, voluntary intake and performance of beef cattle, as well as the capacity of legumes to fix atmospheric $\mathrm{N}$ (and reduce requirement for fertiliser $\mathrm{N}$ inputs) are well recognised (Phelan et al., 2015). Research is commencing on the evaluation of multi-species swards, including grasses, legumes and herbs/ forbs as a means to further increase the resilience of pasturebased beef production systems.

Early finishing of cattle at pasture in autumn is attractive as it eliminates the need for an expensive indoor finishing period. Due to accumulated animal growth and decreasing seasonal grass growth, herd feed demand usually exceeds supply in autumn on most beef farms. Consequently, there may be a role for strategic concentrate supplementation at pasture to enhance feed-nutrient intake, and thus subcutaneous fat deposition and carcass fat score especially of steers and bulls finished at pasture (Lenehan et al., 2017a; Regan et al., 2018). Carcass growth response to concentrate supplementation while grazing will primarily depend on the availability and quality of pasture and level of supplemented concentrate. Concentrate response is higher where grass supply is low and where grass quality is poorer, and declines as concentrate supplementation level increases. Substitution rates for finishing cattle grazing autumn pasture supplemented with concentrates range from 0.1 to 0.8 , with marginal values at higher levels of supplementation in excess of 1.0 in some studies (French et al., 2001a; Lenehan et al., 2017a). At adequate ( $20 \mathrm{~g} / \mathrm{kg}$ live weight) grass allowances in autumn, feeding $\sim 0.50-0.75 \mathrm{~kg}$ of concentrate per $100 \mathrm{~kg}$ live weight resulted in carcass growth responses for steers between 30 and $110 \mathrm{~g}$ carcass per $\mathrm{kg}$ concentrate (Keane \& Drennan, 2008; McNamee et al., 2012). In practice, feeding this moderate level of concentrates will likely result in carcass growth responses at the upper end of this range. Responses of 82-88 g carcass per kg concentrate DM were obtained for suckler bulls (Marren et al., 2015; Lenehan et al., 2017a).

In autumn, the diet of grazing cattle is generally unbalanced because there is usually excess degradable protein in autumn grass (Owens et al., 2008b). Therefore, dietary energy rather than protein is the limiting factor and, where supplementation occurs, concentrate energy sources are required. Animal performance is similar for starch-based (barley) or fibrebased (pulp) concentrates as supplements to autumn grass (Drennan et al., 1997; French et al., 2001b).

\section{Growing/finishing cattle on grass silage diets}

Intake is a major determinant of the performance of cattle consuming grass silage and mechanisms regulating intake are complex (McGee, 2005). Most of the variation in net energy content of grass silage is associated with its digestibility. Silage DMD must improve on beef farms; DMD values above $700 \mathrm{~g} / \mathrm{kg}$ need to become the norm for growing and finishing cattle with values of circa $750 \mathrm{~g} / \mathrm{kg}$ for topperforming animals (O'Kiely, 2015). This will require utilisation of highly productive swards within grassland management systems that optimise both grazing and silage production components. Additionally, much greater emphasis is needed on knowing the yield, digestibility and ensilability of crops pre-harvest, the quantity, nutritive value and preservation characteristics of silage conserved, as well as restricting losses during harvesting, ensilage and feed-out (O'Kiely, 2015). Nevertheless, beef cattle rarely consume sufficient grass silage to achieve their production potential and as a result, energy-rich concentrates are routinely supplemented in practice (McGee, 2005).

Performance of beef cattle increases with increasing grass silage digestibility and the impact of digestibility increases as the proportion of silage in the diet increases (McGee, 2005; Cummins et al., 2007). For example, in finishing cattle, a $10 \mathrm{~g} / \mathrm{kg}$ increase in silage digestibility was associated with an increase in carcass gain of circa $33 \mathrm{~g} / \mathrm{d}$ where silage was the sole feed and 21-29 $\mathrm{g} / \mathrm{d}$ when supplemented with concentrates at $0.20-0.40$ of dietary DMI (McGee, 2005). Conversely, each $10 \mathrm{~g} / \mathrm{kg}$ decline in digestibility requires an additional circa 0.33 $\mathrm{kg}$ concentrate DM daily to sustain performance (Keady et al., 2013b). Substitution rate of concentrates for grass silage is 
a function of silage digestibility and concentrate feed level it increases with both. With high-digestibility grass silage, substitution rates for diets containing $<0.5$ or $>0.5$ dietary DMI as concentrates range from 0.29 to 0.64 and 0.55 to 1.15 $\mathrm{kg}$ silage DM per kg concentrate DM, respectively (McGee, 2005). Inclusion of cereal-based concentrates with grass silage generally has a negative effect on ruminal digestibility of NDF (Owens et al., 2008c); consequently, total diet digestibility does not necessarily increase with supplementation.

Subsequent compensatory growth at pasture diminishes the advantage of concentrate supplementation of young "weanling" cattle offered grass silage; consequently, live weight gains of $0.5-0.6 \mathrm{~kg} / \mathrm{d}$ through the "first" winter are acceptable for steers, heifers and suckler bulls destined to return to pasture in spring (Marren et al., 2013; McGee et al., 2014). This also applies to older "store" cattle in their second winter destined for subsequent finishing at pasture (Keane \& Drennan, 2008; Keane \& Moloney, 2009). However, a higher level of feeding is generally warranted during the first winter for "replacement" beef heifers (Heslin et al., 2020). The production response to concentrate supplementation is higher with lower-digestibility silage (McGee, 2005). For finishing cattle offered highdigestibility grass silage, the growth response to concentrate supplementation - increasing from $\sim 2$ to $10 \mathrm{~kg} / \mathrm{head}$ daily - is generally curvilinear (McGee, 2005; Keane et al., 2006). Due to this progressive decline in growth response to concentrates, high-digestibility grass silage plus moderate concentrate inputs can achieve a large proportion of the carcass and lean tissue gain achieved with high-concentrate diets. Accordingly, in order to determine the optimum or breakeven level of concentrate supplementation per se, estimates of carcass efficiency ( $\mathrm{kg}$ concentrates per kg carcass), silage substituted (kg DM per kg carcass gain) and the true costs of grass silage and concentrates are required (McGee, 2015). In addition to dietary feeding value, efficiency of feed utilisation primarily depends on weight of animal (decreases as live weight increases), potential for carcass growth (e.g. breed type, genetic merit, animal sex, compensatory growth potential) and duration (decreases as length increases) of the finishing period (McGee, 2015; McGee et al., 2018a). High-concentrate diets are predominantly used to finish bulls, including animals previously grazing (O'Riordan et al., 2011b).

Although barley is widely used as a supplement with grass silage, wheat (Drennan et al., 2006), oats (McGee et al., 2018b) or maize (Lenehan et al., 2015b) can be equally effective. Similarly, by-product feed ingredients including molassed sugar-beet pulp (Keane, 2005), citrus pulp (Lenehan et al., 2017b), palm kernel expeller meal (Magee et al., 2016), corn gluten feed (Kelly et al., 2018), maize-dried distillers grains (Magee et al., 2015a) and soya hulls (Magee et al., 2015b) can fully or partially replace rolled barley in concentrate rations as a supplement to grass silage without negatively impacting animal performance. However, due to "associative effects" the relative feeding (and economic value) of by-product feed ingredients is contingent on concentrate feeding practices, such as inclusion level in the concentrate ration and the amount of concentrates fed.

The CP concentration of commercial "growing" and "finishing" concentrates for beef cattle in Ireland often seems excessively high in relation to animal requirements. Indeed, the general perception is that the higher the CP percentage, the "better" the concentrate. In most cases, diets are formulated with minimal consideration for current concepts of protein metabolism such as rumen-degradable or undegradable protein. The growth response in "weanling" cattle, even bulls, to additional protein above that supplied in a barley onlybased concentrate as a supplement to high-nutritive value grass silage is small (Lenehan et al., 2015c). For "finishing" cattle offered high-digestibility grass silage plus barleybased concentrates, increasing protein supply from either a rumen-degradable or undegradable protein source did not significantly affect animal growth (McGee, 2005; Kennedy et al., 2021), implying that concentrate CP concentrations of $\sim 100 \mathrm{~g} / \mathrm{kg}$ fresh-weight basis, which is $20 \%-50 \%$ lower than commercially available concentrate rations, may suffice under such conditions. Recent research is evaluating the role of indigenous protein feedstuffs, including faba beans and peas, in beef cattle rations (Kennedy et al., 2021) in order to increase self-sufficiency nationally.

Concentrate supplementation feeding strategies include feeding frequency, complete diet feeding/TMR, co-ensiling, concentrate distribution pattern and restricted feeding (McGee, 2005). Offering cereal-based rations comprising circa 0.50 dietary DMI in one as opposed to two daily feeds (Drennan et al., 2006) or mixing of grass silage and barleybased concentrates in a TMR compared to separate feeding (Keane et al., 2006) had no effect on animal efficiency or performance. Feeding weanling cattle a fixed total concentrate allowance offered at a flat daily rate or at a higher rate over the first half of the winter gave a better growth response than when offered at a higher rate over the second half of the winter (Keane, 2002). In finishing cattle offered grass silage feeding, a fixed total quantity of concentrates at a flat rate or varied pattern resulted in similar efficiency of feed energy utilisation (Cummins et al., 2007).

\section{Suckler cow nutrition}

In spring-calving grass-based calf-to-weanling and calf-tobeef systems, the cow-herd consumes approximately $85 \%$ and $50 \%$ or greater of total feed inputs, respectively (Lawrence et al., 2013). Nutrition of spring-calving suckler cows generally involves feed energy restriction and mobilisation 
of body fat reserves during the indoor winter period when feed costs are high and deposition of body reserves on cheaper-produced pasture (Drennan \& McGee, 2004). The robustness of cow genotypes to deal with such contrasting nutritional environments has implications for animal breeding programmes. A negative linear relationship exists between cow winter-weight loss and subsequent gain at pasture; indeed, a compensatory growth-like occurrence is evident (Drennan \& McGee, 2004). These annual changes in body reserves, however, need to be within the boundaries of target BCS at key stages of the production cycle - late pregnancy, calving and breeding - in order to maintain good reproductive performance (Drennan \& Berry, 2006), as well as avoiding nutritionally induced calving difficulty. As plane of nutrition is manifested through body reserves, BCS is a key practical tool for nutritional management of suckler cows.

Cows offered grass silage of reduced DMD during late pregnancy have lower DMI and greater weight loss compared to those offered higher DMD silage (Drennan \& McGee, 2004) although calf BW is generally unaffected as energy partition is prioritised towards foetal growth. Suckler cows in good BCS $(\sim 3.0+$, scale $0-5)$ at housing in autumn can be restricted to circa $75 \%-85 \%$ of feed energy requirements. This restriction can be applied through various approaches depending on silage digestibility, including offering moderate DMD ( 660 $\mathrm{g} / \mathrm{kg}$ ) silage ad libitum (Drennan \& McGee, 2004), restricting silage intake (McGee et al., 2005) or reducing dietary energy value through inclusion of straw (McGee \& Earley, 2013). When offered moderate DMD grass silage ad libitum, DMI relative to live weight ranges from 11.0 to $15.0 \mathrm{~g} / \mathrm{kg}$ across contrasting suckler cow genotypes in late pregnancy (McGee et al., 2005; Minchin \& McGee, 2011). This ad libitum silagefeeding regime is practical as the forage characteristics result in self-regulation of intake and nutrient supply. However, because the annual national DMD of silage nationally ranges between 600 and $640 \mathrm{~g} / \mathrm{kg}$ (O'Kiely, 2015), this means that concentrate supplementation for suckler cows is required on many farms to achieve an adequate plane of nutrition.

Multiparous cows in moderate BCS postpartum can tolerate the negative energy balance associated with consuming moderate DMD grass silage ad libitum in early lactation provided they are calving relatively close to commencement of grazing, but primiparous, thin and early calving cows require a higher plane of nutrition particularly to avoid delayed oestrous cyclicity. Maintaining a 365-d calving interval is critical to spring-calving suckler herds (Diskin \& Kenny, 2014). McGee et al. (1998) showed that primiparous suckler cows offered grass silage supplemented with $2 \mathrm{~kg}$ of concentrates daily postpartum had less weight loss and greater milk yield resulting in greater early life calf growth than those offered only grass silage. Milk, a primary source of nutrients for the suckled calf in early postnatal life, remains a significant component of the diet until weaning, and thus, is a primary driver of calf pre-weaning growth (Sapkota et al., 2020).

Early turnout to pasture in spring increases grazed grass in the annual diet of the cow. Restricted access grazing, when soil or weather conditions are poor, is a nutritional management strategy resulting in at least comparable cow performance, and transitory benefits in calf growth, compared to those housed indoors on grass silage-based diets (Gould et al., 2010, 2011b). Grazed grass DMI relative to live weight ranges from 17 to $24 \mathrm{~g} / \mathrm{kg}$ for contrasting lactating suckler cow genotypes (Gould et al., 2011a; Lawrence et al., 2013; McCabe et al., 2017, 2019), which are comparable to zerograzed intakes (Murphy et al., 2008). Grass alone is generally sufficient to meet the nutrient requirements of single-suckling lactating cows in rotationally grazed systems when herbage supply is not limited (Drennan \& McGee, 2009). Under these circumstances, cow live weight gains up to circa $100 \mathrm{~kg}$ during the grazing season are achievable, especially with low-milk yield genotypes and multiparous animals (McGee et al., 2005; Drennan \& Berry, 2006). However, cows that are very highly stocked or offered low herbage allowances have lower live weight and/or BCS gains and, in more severe cases, lower milk yield resulting in lower pre-weaning growth of their progeny compared to those on low stocking rates (Drennan \& McGee, 2008). Similarly, lactating suckler cows grazing to low residual sward heights $(4.1 \mathrm{vs} .5 .3 \mathrm{~cm})$ gained less weight and body condition, and had lighter calves at weaning than those grazing to a higher residual height (Minchin et al., 2011). Live weight gains of spring-born single-sucking unsupplemented calves on well-managed rotationally grazed systems typically exceed $1.1 \mathrm{~kg}$ daily over the grazing season, although this is heavily influenced by dam milk yield (McGee et al., 2005; McCabe et al., 2019). Calf growth responses to "creep feeding" suckled calves at pasture in late lactation with energy-based concentrates can range from 60 to $190 \mathrm{~g}$ live weight per kg concentrate (McGee et al., 1996).

\section{Mitigation of rumen methane by nutrition management - developments and challenges}

Methane gas is a by-product of the microbial fermentation of ingested feed by ruminant animals and is a notable energy loss to the animal (Johnson \& Johnson, 1995). It is also an acknowledged potent greenhouse gas (GHG) and makes a significant contribution to anthropogenic GHG emissions (Martinez-Fernandez et al., 2018). The development of dietary supplements to mitigate methane emissions from ruminant livestock either directly through inhibiting microbial methanogenic biosynthetic pathways or indirectly through limiting the availability of its precursor hydrogen to methanogenic archaea is a key focus of research worldwide. 
Historically, halogenic compounds such as bromoform and chloroform have been studied for their efficacy as antimethanogenic compounds (Bauchop, 1967; Russel \& Martin, 1984). However, they are currently mainly used as experimental controls (Martinez-Fernandez et al., 2018) due to their strong anti-methanogenic albeit toxic and carcinogenetic qualities. This has also been the case for ionophores such as monensin (an antibiotic) which deplete the rumen microbiome and therefore inhibit methanogenesis. Antibiotics were previously fed to animals as growth promoters, particularly in the United States. However, they are now banned for use as growth promoters in the EU as of 2006 due to issues with resistance and human health concerns (EMA, 2007).

Hristov et al. (2013) listed the efficacy of various livestock dietary additives for reducing $\mathrm{CH}_{4}$ emissions. This study highlighted the potential of lipid inclusion in ruminant diets, seaweed algae and 3-nitrooxypropanol (3-NOP) to substantially reduce methane emissions.

The addition of fats and oils as methane abatement compounds to ruminant diets has been promising. Lipids result in an antagonism in methane production as they are toxic to and therefore reduce methanogens and protozoa numbers (Beauchemin et al., 2009; Broucek, 2018). However, fat addition can negatively affect feed intake, carbohydrate digestion in the rumen and overall milk quality. There are also issues surrounding sulphide toxicity at high fat intake levels. As regards plant-based oil seeds, Kliem et al. (2019) found that only linseed-based supplements reduced methane emissions (across production, yield and emissions intensity) when comparing the administration of linseed, palm and rapeseed oil products to dairy cows. Similarly, Boland et al. (2020) reported an 18\% decrease in emission intensity (g $\mathrm{CH}_{4} / \mathrm{kg}$ milk) from pasture-fed dairy cows receiving linseed oil-based concentrates compared with cows receiving stearic acid- or soy oil-based concentrates.

There are also a range of industrially formulated products with the potential to reduce methanogenesis such as Mootral (a feed additive containing allicin from garlic and citrus extracts) and Agolin Ruminant (an essential oil blend). Studies have shown positive, albeit variable effects of both products on reducing the amount and rate of enteric $\mathrm{CH}_{4}$ production in both dairy and beef cattle (Hargreaves et al., 2019; Belanche et al., 2020). Agolin Ruminant has also been shown to improve livestock productivity (particularly dairy), which could potentially reduce intensity of methane emissions. It is also cheap to buy rendering it a potential, affordable solution. However, both of these additives are in need of further trials under different dietary regimes (Roque et al., 2019a).

Seaweed, in particular Asparagopsis taxiformis (Delile) Trevis. contains anti-methanogenic properties. Many studies have seen significant reductions in methane emissions from livestock receiving seaweed-based additives at various administration rates and concentrations (Machado et al., 2016; Roque et al., 2019b). Further work is required to understand the potential long-term effects on animal productivity and health. There are concerns surrounding the concentrations of both bromoform (a potential carcinogen) and iodine within red seaweeds, which could potentially carry through the food chain. However, this is not the case with brown seaweeds where there is still potential for safe use as a methane inhibitor, although this is in need of further research and validation (Antaya et al., 2019). The supply, consistency and sustainable use of seaweeds may be an issue as regards the feasibility of growing seaweeds or the environmental impact of harvesting wild crops. Work is also ongoing to assess seaweed extracts for their anti-methanogenic capability.

The synthetic non-toxic compound, 3-NOP, is a promising methane inhibitor which has displayed consistent methane yield decreases of $20 \%-40 \%$ depending upon animal type, diet composition, dose and method of supplementing 3-NOP (Haisan et al., 2014, 2017; Martinez-Fernandez et al., 2014; Hristov et al., 2015; Vyas et al., 2016, 2018a, 2018b; Beauchemin et al., 2020). Many studies have reported the positive effects of 3-NOP in vitro (Anderson et al., 2010; Guyader et al., 2017) as well as in vivo in sheep (MartinezFernandez et al., 2014), dairy cows (Haisan et al., 2017) and beef cattle (Romero-Perez et al., 2014). Furthermore, a metaanalysis of in vivo studies concluded that dietary inclusion of 3-NOP does not compromise the productive performance of ruminant animals (Jayanegara et al., 2018). However, consumer behaviour will need to be considered before it is adopted as an on-farm mitigation option, that is, there may be issues surrounding the consumption of products that arise from animals fed on synthetic compounds (Beauchemin et al., 2020). Three meta-analyses have concluded that 3-NOP is effective in mitigating enteric methane emissions without negatively impacting animal performance (Dijkstra et al., 2018; Jayanegara et al., 2018; Kim et al., 2020). A review of growing-cattle studies showed that feeding 3-NOP had no effect on DMI but daily methane production and yield was decreased by $50 \%$ (van Gastelen et al., 2019).

Evidence from Teagasc work and elsewhere suggests that changes in microbial colonisation of the rumen during the early postnatal period may imprint the rumen microbiome with lasting effects on biochemical functionality including methanogenesis, which extend into later life (Jami et al., 2013; O'Hara et al., 2020). Work to date shows clearly that the first month of life presents a time-frame during which the rumen micobiome becomes established but is also susceptible to environmental influence, including diet. This presents a potential opportunity for manipulation of both the composition and functionality of the microbiome through strategic dietary supplementation. Recently, Meale et al. (2021) showed that early life administration (oral dose) of dairy calves with 3-NOP from 
birth to 14 wk of life resulted in a marked reduction in methane emissions, which persisted to 12 mo of age. This equated to a cumulative reduction of circa $150 \mathrm{~kg}$ of $\mathrm{CO}_{2}$ eq per head in these cattle during the first year of life (Meale et al., 2021).

Within grass-based production systems, the use of such feed additives is currently best suited to the indoor winter feeding periods. In order for 3-NOP or any other additive to be an effective option for methane mitigation on grass-based systems as in Ireland, a slow-release rumen bolus form of the additive is required for sustained effectiveness. Efforts are underway to produce inhibitors suitable for grazing-based systems and alternative formulations containing 3-NOP (Leahy et al., 2020). A slow release option has examined initial prototypes which were able to extend methane reduction from feeding time to $6-8 \mathrm{~h}$ with one small dose delivered in a supplemental feed. The new slow release formulations of 3-NOP were tested and showed potential to extend the time that 3-NOP is active in the rumen, based on gas emission profiles from cows (Muetzel et al., 2019). Further studies are planned to refine promising formulations and to establish their methane reduction potential for pasture-fed cattle.

\section{Summary and conclusions}

Ruminant-based agriculture faces increasing scrutiny as to its role in global food systems due to issues around environmental and social impact, land use efficiency and product quality. In such circumstances, the relative sustainability of ruminant systems may increasingly require leveraging of their utility as converters of indigestible plant material into high-value human-edible protein. In practice, this will mean maximising the contribution of highly digestible forage to the overall diet. Research across sheep, beef and dairy systems in Ireland has demonstrated the capacity for quality grazed pasture and conserved forages to deliver diets with high-nutrient content, good feed intake characteristics and excellent animal health and productivity potential. Improved understanding of the role of fibre fractions in determining nutrient supply has been of particular importance to development of feed and forage management guidelines. Furthermore, the refinement of protein nutrition guidelines to an $\mathrm{AA}$ content rather than $\mathrm{N}$ content has provided opportunities for greater animal performance and nutrient-use efficiencies. Where feed supplementation is practised, it has been demonstrated that factors such as basal forage quality, the animal's genetics and physiological state, as well as supplement rate and type, all contribute to physical and economic responses. Consideration must also be given to the likely effects on nutrient balances and potential losses to the environment. Inclusion of specific dietary factors to reduce gaseous emissions has shown promise but requires optimisation for grazing systems. Pasture management and animal feeding can sometimes be viewed as unrelated or even competing disciplines at farm level. A continuing challenge for research and extension is to develop and embed the concept of excellent pasture and forage quality as a cornerstone of animal nutrition programmes. Further integration of prediction models for forage intake, animal response models and realtime analysis of feed and forage composition will enhance management decisions in this regard.

\section{References}

Abdela, N. 2016. Sub-acute ruminal acidosis (SARA) and its consequence in dairy cattle: a review of past and recent research at global prospective. Achievements in the Life Sciences 10: 187-196.

Ahvenjärvi, S. 2006. Measurement of digesta flow entering the omasal canal. In: "Ruminant Physiology: Digestion, Metabolism and Impact of Nutrition on Gene Expression, Immunology and Stress" (eds. K. Sejrsen, T. Hvelplund and M.O. Nielsen), Wageningen Academic Publisher, Wageningen, The Netherlands, pages 587-589.

Alothman, M., Hogan, S.A., Hennessy, D., Dillon, P., Kilcawley, K.N., O'Donovan, M., Tobin, J., Fenelon, M.A. and O'Callaghan, T.F. 2019. The "grass-fed" milk story: understanding the impact of pasture feeding on the composition and quality of bovine milk. Foods 8: 350 .

Anderson, R.C., Huwe, J.K., Smith, D.J., Stanton, T.B., Krueger, N.A., Callaway, T.R., Edrington, T.S., Harvey, R.B. and Nisbet, D.J. 2010. Effect of nitroethane, dimethyl-2-nitroglutarate and 2-nitromethyl-propionate on ruminal methane production and hydrogen balance in vitro. Bioresource Technology 101: 5345-5349.

Antaya, N.T., Ghelichkhan, M., Pereira, A.B.D., Soder, K.J. and Brito, A.F. 2019. Production, milk iodine, and nutrient utilization in Jersey cows supplemented with the brown seaweed Ascophyllum nodosum (kelp meal) during the grazing season. Journal of Dairy Science 102: 8040-8058.

Aufrère, J., Baumont, R., Delaby, L., Peccatte, J.R., Andrieu, J., Andrieu, J.R. and Dulphy, J.P. 2007. Laboratory prediction of forage digestibility by the pepsin-cellulase method. The renewed equations. INRA Production Animales 20: 129-136.

Bargo, F., Muller, L.D., Kolver, E.S. and Delahoy, J.E. 2003. Invited review: Production and digestion of supplemented dairy cows on pasture. Journal of Dairy Science 86: 1-42.

Bauchop, T. 1967. Inhibition of rumen methanogenesis by methane analogues. Journal of Bacteriology 94: 171-175.

Baudracco, J., Lopez-Villalobos, N., Holmes, C. and Macdonald, K. 2010. Effects of stocking rate, supplementation, genotype and their interactions on grazing dairy systems: a review. NZ Journal Agricultural Research 53: 109-133.

Beauchemin, K.A., McAllister, T.A. and McGinn, S.M. 2009. Dietary mitigation of enteric methane from cattle. CAB Reviews: Perspectives in Agriculture, Veterinary Science, Nutrition and Natural Resources 4: 1-18. 
Beauchemin, K.A., Ungerfeld, E.M., Eckard, R.J. and Wang, M. 2020. Review: Fifty years of research on rumen methanogenesis: lessons learned and future challenges for mitigation. Animal 14: 2-16.

Beecher, M., Buckley, F., Waters, S.M., Boland, T., EnriquezHidalgo, D., Deighton, M., O'Donovan, M. and Lewis, E. 2014. Gastrointestinal tract size, total-tract digestibility, and rumen microflora in different dairy cow genotypes. Journal of Dairy Science 97: 3906-3917.

Beecher, M., Hennessy, D., Boland, T., McEvoy, M., O'Donovan, M. and Lewis, E. 2015. The variation in morphology of perennial ryegrass cultivars throughout the grazing season and effects on organic matter digestibility. Grass and Forage Science 70: 19-29.

Beecher, M., Baumont, R., O'Donovan, M., Boland, T., Aufrere, J., Fleming, C., Galvin, N. and Lewis, E. 2018. Effects of harvesting perennial ryegrass at different levels of herbage mass on voluntary intake and in vivo digestibility in sheep. Grass and Forage Science 73: 553-561.

Belanche, A., Newbold, C.J., Morgavi, D.P., Bach, A., Zweifel, B. and Yáñez-Ruiz, D.R. 2020. A meta-analysis describing the effects of the essential oils blend Agolin Ruminant on performance, rumen fermentation and methane emissions in dairy cows. Animals 10: 620.

Berry, D.P., Buckley, F., Dillon, P., Evans, R.D., Rath, M. and Veerkamp, R.F. 2003. Genetic relationships among body condition score, body weight, milk yield, and fertility in dairy cows. Journal of Dairy Science 86: 2193-2204.

Berry, D.P., Friggens, N.C., Lucy, M. and Roche, J.R. 2016. Milk production and fertility in cattle. Annual Review of Animal Biosciences 4: 269-290.

Boland, T.M., Pierce, K.M., Kelly, A.K., Kenny, D.A., Lynch, M.B., Waters, S.M., Whelan, S.J. and McKay, Z.C. 2020. Feed intake, methane emissions, milk production and rumen methanogen populations of grazing dairy cows supplemented with various $\mathrm{C} 18$ fatty acid sources. Animals 10: 2380.

Broderick, G.A., Huhtanen, P., Ahvenjärvi, S., Reynal, S.M. and Shingfield, K.J. 2010. Quantifying ruminal nitrogen metabolism using the omasal sampling technique in cattle - a meta-analysis. Journal of Dairy Science 93: 3216-3230.

Broucek, J. 2018. Options to methane production abatement in ruminants: a review. Journal of Animal and Plant Sciences 28: 348-364.

Bruinenberg, M.H., van der Honing, Y., Agnew, R.E., Yan, T., van Vuuren, A.M. and Valk, H. 2002. Energy metabolism of dairy cows fed on grass. Livestock Production Science 75: 117-128.

Buckley, F., Dillon, P., Rath, M., and Veerkamp, R.F. 2000. The relationship between genetic merit for yield and live weight condition score, and energy balance of spring calving HolsteinFriesian dairy cows on grass based systems on milk production. Journal of Dairy Science 83: 1878-1886.

Buckley, F., O'Sullivan, K., Mee, J.F., Evans, R.D. and Dillon, P. 2003. Relationships among milk yield, body condition, cow weight, and reproduction in spring-calved Holstein-Friesians. Journal of Dairy Science 86: 2308-2319.

Burke, F., Murphy, J.J., O'Donovan, M.A., O’Mara, F.P., Kavanagh, S. and Mulligan, F.J. 2007. Comparative evaluation of alternative forages to grass silage in the diet of early lactation dairy cows. Journal of Dairy Science 90: 908-917.

Burke, F., O'Donovan, M.A., Murphy, J.J., O'Mara, F.P. and Mulligan, F.J. 2008. Effect of pasture allowance and supplementation with maize silage and concentrates differing in crude protein concentration on milk production and nitrogen excretion by dairy cows. Livestock Science 114: 325-335.

Butler, M., Patton, J., Murphy, J.J. and Mulligan, F.J. 2011. Evaluation of a high-fibre total mixed ration as a dry cow feeding strategy for spring-calving Holstein Friesian dairy cows. Livestock Science 136: 85-92.

Central Statistics Office, Ireland. 2020. Available online: https://www. cso.ie/en/statistics/agriculture/ [Accessed 20 August 2021].

Chen, A., Bryant, R.H. and Edwards, G.R. 2019. Morphology and nutritive value of perennial ryegrass cultivars at different phenological stages. Grass and Forage Science 74: 576-581.

Chestnutt, D.M.B. 1989. Effect of silage quality on the performance of pregnant ewes. In: "Sheep Production", Occasional Publication, No. 17. Agricultural Research Institute of Northern Ireland, pages 3-14.

Clarke, A.M., Drennan, M.J., McGee, M., Kenny, D.A., Evans, R.D. and Berry, D.P. 2009. Intake, growth and carcass traits in male progeny of sires differing in genetic merit for beef production. Animal 3: 791-801.

Coleman, J., Pierce, K.M., Berry, D.P., Brennan, A. and Horan, B. 2009. The influence of genetic selection and feed system on the reproductive performance of spring-calving dairy cows within future pasture-based production systems. Journal of Dairy Science 92: 5258-5269.

Cotanch, K.W., Grant, R.J., Van Amburgh, M.E., Zontini, A., Fustini, M., Palmonari, A. and Formigoni, A. 2014. Applications of UNDF in ration modeling and formulation. Proceedings of Cornell Nutrition Conference, Syracuse, Cornell University, Ithaca, New York, pages 114-131.

Crowe, M.A., Hostens, M. and Opsomer, G. 2018. Reproductive management in dairy cows-the future. Irish Veterinary Journal 71: $1-13$.

Cummins, B., Keane, M., O'Kiely, P. and Kenny, D. 2007. Effects of breed type, silage harvest date and pattern of offering concentrates on intake, performance and carcass traits of finishing steers. Irish Journal of Agricultural and Food Research 46: 149-168.

Cummins, S.B., Lonergan, P., Evans, A.C.O., Berry, D.P., Evans, R.D. and Butler, S.T. 2012. Genetic merit for fertility traits in Holstein cows: I. Production characteristics and reproductive efficiency in a pasture-based system. Journal of Dairy Science 95: $1310-1322$.

Curran, F., Wall, D., Lonergan, P. and Butler, S. 2016. Survey of temporal variation in pasture mineral concentrations and total 
dietary mineral intake in pasture-based dairy herds. Journal of Animal Science 94: 292-292.

Dechow, C.D., Baumrucker, C.R., Bruckmaier, R.M. and Blum, J.W. 2017. Blood plasma traits associated with genetic merit for feed utilization in Holstein cows. Journal of Dairy Science 100: 8232-8238.

Delagarde, R., Peyraud, J. and Delaby, L. 1997. The effect of nitrogen fertilization level and protein supplementation on herbage intake, feeding behaviour and digestion in grazing dairy cows. Animal Feed Science and Technology 66: 165-180.

Department of Environment, Climate Change and Communications. Ireland. 2021. Climate Action Plan 2021. Available online: https:// www.gov.ie/en/publication/6223e-climate-action-plan-2021/ [Accessed 10 November 2021].

Dijkstra, J., Bannink, A., France, J., Kebreab, E. and van Gastelen, S. 2018. Short communication: antimethanogenic effects of 3-nitrooxypropanol depend on supplementation dose, dietary fiber content, and cattle type. Journal of Dairy Science 101: 9041-9047.

Dillon, P. 2006. Achieving high dry-matter intake from pasture with grazing dairy cows. In: "Fresh Herbage for Dairy Cattle" (eds. A. Elgersma, J. Dijkstra and S. Tamminga), Springer Press, pages 1-26.

Dineen, M., McCarthy, B., Dillon, P., LaPierre, P.A., Fessenden, S., Mattews, C., Galvin, N. and Van Amburgh, M.E. 2020. Rumen metabolism, omasal flow of nutrients, and microbial dynamics in lactating dairy cows fed fresh perennial ryegrass (Lolium perenne L.) non-supplemented or supplemented with rolled barley grain. Journal of Dairy Science 103: 11332-11348.

Dineen, M., McCarthy, B., Dillon, P., Mattews, C., Ross, D. and Van Amburgh, M.E. 2021a. Microbial composition and omasal flows of bacterial, protozoal, and nonmicrobial amino acids in lactating dairy cows fed fresh perennial ryegrass (Lolium perenne L.) not supplemented or supplemented with rolled barley. Journal of Dairy Science 104: 4192-4205.

Dineen, M., McCarthy, B., Ross, D., Ortega, A., Dillon, P. and Van Amburgh, M.E. 2021b. Characterization of the nutritive value of perennial ryegrass (Lolium perenne L.) dominated pastures using updated chemical methods with application for the Cornell Net Carbohydrate and Protein System. Animal Feed Science and Technology 272: 114752.

Diskin, M.G. and Kenny, D.A. 2014. Optimising reproductive performance of beef cows and replacement heifers. Animal 8: 27-29.

Douglas, M., Auldist, M., Jacobs, J., Hannah, M., Garcia, S. and Wales, W. 2020. Quantifying the ruminal degradation of nutrients in three cultivars of perennial ryegrass (Lolium perenne L.) sampled during early spring and summer. Animal Production Science 60: 370-378.

Douglas, M.L., Auldist, M.J., Wright, M.M., Marett, L.C., Russo, V.M., Hannah, M.C., Garcia, S.C. and Wales, W.J. 2021. Using estimated nutrient intake from pasture to formulate supplementary concentrate mixes for grazing dairy cows. Journal of Dairy Science 104: 4350-4361.

Dowman, M.G. and Collins, F.C. 1982. The use of enzymes to predict the digestibility of animal feeds. Journal of the Science of Food and Agriculture 33: 689-696.
Doyle, P., Kelly, A.K., McGee, M., Moloney, A.P. and O'Riordan, E.G. 2019. Effect of pre-grazing herbage mass on performance of early- and late-maturing suckler-bred steers. Advances in Animal Biosciences 10: 64.

Doyle, P., McGee, M., Moloney, A.P., Kelly, A.K. and O'Riordan, E.G. 2020. Effect of post-grazing sward height, finishing diet and sire breed on performance of suckler steers. Grassland Science in Europe 25: 243-245.

Doyle, P.R., McGee, M., Moloney, A.P., Kelly, A.K. and O'Riordan, E.G. 2021. PSIV-8 Effect of pre-grazing herbage mass, postgrazing sward height and finishing diet on performance of latematuring beef steers. Journal of Animal Science 99: 296.

Drennan, M.J. and Berry, D.P. 2006. Factors affecting body condition score, live weight and reproductive performance in spring-calving suckler cows. Irish Journal of Agricultural and Food Research 45: 25-38.

Drennan, M.J. and McGee, M. 2004. Effect of suckler cow genotype and nutrition level during the winter on voluntary intake and performance and on the growth and slaughter characteristics of their progeny. Irish Journal of Agricultural and Food Research 43: 185-199.

Drennan, M.J. and McGee, M. 2008. Performance of spring-calving beef suckler cows and their progeny on four contrasting grassland management systems. Livestock Science 117: 238-248.

Drennan, M.J. and McGee, M. 2009. Performance of spring-calving beef suckler cows and their progeny to slaughter on intensive and extensive grassland management systems. Livestock Science 120: $1-12$.

Drennan, M.J., Moloney, A.P., O'Riordan, E.G. and McGee, M. 1997. Effects of supplementary concentrates on performance of finishing heifers at pasture in autumn. Proceedings of the Agricultural Research Forum, UCD, Belfield, Dublin, pages 261-262.

Drennan, M.J., McGee, M. and Moloney, A.P. 2006. The effect of cereal type and feeding frequency on intake, rumen fermentation, digestibility, growth and carcass traits of finishing steers offered a grass silage-based diet. Irish Journal of Agricultural and Food Research 45: 135-147.

Ellis, W.C., Mahlooji, M. and Matis, J.H. 2005. Models for estimating parameters of neutral detergent fiber digestion by ruminal microorganisms. Journal of Animal Science 83: 1591-1601.

Enriquez-Hidalgo, D., Hennessy, D., Gilliland, T., Egan, M., Mee, J.F. and Lewis, E. 2014. Effect of rotationally grazing perennial ryegrass white clover or perennial ryegrass only swards on dairy cow feeding behaviour, rumen characteristics and sward depletion patterns. Livestock Science 169: 48-62.

Environmental Protection Agency. 2021. Ireland's provisional greenhouse gas emissions 1990-2020. Available online: https:// www.epa.ie/publications/monitoring--assessment/climate-change/ air-emissions/Irelands-Provisional-Greenhouse-Gas-Emissionsreport-1990-2020_finalv2.pdf [Accessed 10 November 2021].

European Medicines Agency. 2007. Committee for medicinal products for veterinary use: Monensin. EMEA/CVMP/185123/2007-Final. 
European Union Commission. 2020. Farm to Fork Strategy. Available online: https://eur-lex.europa.eu/legal-content/EN/ TXT/?uri=CELEX:52020DC0381 [Accessed 26 August 2021].

Faverdin, P., Baratte, C., Delagarde, R. and Peyraud, J.L. 2011. Grazeln: a model of herbage intake and milk production for grazing dairy cows. 1. Prediction of intake capacity, voluntary intake and milk production during lactation. Grass and Forage Science 66: 29-44.

Ferris, C.P., Gordon, F.J., Patterson, D.C., Kilpatrick, D.J., Mayne, C.S. and McCoy, M.A. 2001. The response of dairy cows of high genetic merit to increasing proportion of concentrate in the diet with a high and medium feed value silage. The Journal of Agricultural Science 136: 319-329.

Finneran, E., Crosson, P., O'Kiely, P., Shalloo, L., Forristal, D. and Wallace, M. 2011. Economic modelling of an integrated grazed and conserved perennial ryegrass forage production system. Grass and Forage Science 67: 162-176.

Finneran, E., Crosson, P., O'Kiely, P., Shalloo, L., Forristal, D. and Wallace, M. 2012. Stochastic simulation of the cost of homeproduced feeds for ruminant livestock systems. The Journal of Agricultural Science 150: 123-139.

Fitzgerald, J.J. 1996. Grass silage as a basic feed for store lambs. 3. Effect of barley supplementation of silages varying in chop length on silage intake and lamb performance. Grass and Forage Science 51: 389-403.

Fitzsimons, C., Kenny, D.A., Deighton, M., Fahey, A.G. and McGee, M. 2013. Methane emissions and rumen fermentation variables of beef heifers differing in phenotypic residual feed intake. Journal of Animal Science 91: 5789-5800.

Food and Agriculture Organization of the United Nations. 2020. Emissions due to agriculture- global regional and country trends 2008-2018. FAOSTAT Analytical Brief Series no 18. Available online: https://www.fao.org/publications/card/en/c/CB3808EN/.

French, P., O'Riordan, E.G., Moloney, A.P., O'Kiely, P. and Caffrey, P.J. 2001a. Effects of concentrate level and grazing system on the performance of beef cattle grazing autumn herbage. Irish Journal of Agricultural and Food Research 40: 33-44.

French, P., Moloney, A.P., O'Kiely, P., O'Riordan, E.G. and Caffrey, P.J. 2001b. Growth and rumen digestion characteristics of steers grazing autumn grass supplemented with concentrates based on different carbohydrate sources. Animal Science $\mathbf{7 2}$ : 139-148.

Ganche, E., Delaby, L., O'Donovan, M., Boland, T.M., Galvin, N. and Kennedy, E. 2013. Post-grazing sward height imposed during the first 10 weeks of lactation: influence on early and total lactation dairy cow production, and spring and annual sward characteristics. Livestock Science 157: 299-311.

Garry, B. 2016. The effect of animal and sward factors on the in vivo organic matter digestibility of perennial ryegrass. $\mathrm{PhD}$ thesis, National University of Ireland, University College Dublin, Belfield, Dublin 4.

Garry, B., O'Donovan, M., Beecher, M., Delaby, L., Fleming, C., Baumont, R. and Lewis, E. 2018. Predicting in vivo digestibility of perennial ryegrass using the neutral detergent cellulase method: updating the equation. Proceedings of the 27th General Meeting of the European Grassland Federation, Cork, Ireland, pages 194-196.

Garry, B., McGovern, F.M., Boland, T.M., Baumont, R., Lewis, E. and O'Donovan, M. 2020. Effects of perennial ryegrass variety and ploidy on voluntary dry matter intake and in vivo digestibility in sheep. Livestock Science 240: 104164.

Garry, B., McGovern, F.M., Boland, T.M., Rinne, M., Kuoppala, K., Baumont, R., Lewis, E. and O'Donovan, M. 2021. How does herbage mass effect voluntary dry matter intake and in vivo organic matter digestibility in sheep and the in vitro gas production of perennial ryegrass? Livestock Science 244: 104345.

Gould, N., McGee, M., Kenny, D.A, Minchin, W., Lawrence, P. and O'Riordan, E.G. 2010. Effect of restricted access time to pasture in spring on the performance of autumn- and spring-calving beef suckler cows and their progeny. Advances in Animal Biosciences, page 208.

Gould, N., Kenny, D.A., Lawrence, P., Minchin, W. and McGee, M. 2011a. Effect of initial grazing date in spring on intake and performance of yearling beef heifers and on yield and nutritive value of swards designated for silage production. Proceedings of the Agricultural Research Forum, Tullamore, Ireland, page 153.

Gould, N., Minchin, W., Kenny, D.A., Fahey, A.G. and McGee, M. 2011b. Effect of initial grazing date in spring, via restricted or full time grazing, on intake and performance of primiparous beef suckler cows and their progeny. Proceedings of the Agricultural Research Forum, Tullamore, Ireland, page 152.

Gordon, F.J. 1982. The effects of degree of chopping grass for silage and method of concentrate allocation on the performance of dairy cows. Grass and Forage Science 37: 59-66.

Grennan, E.J. and McNamara, N. 2005. Finishing lambs on summer pasture and response to creep feeding. Teagasc End of Project Reports: Sheep Series No. 23, pages 1-21.

Guyader, J., Ungerfeld, E.M. and Beauchemin, K.A. 2017. Redirection of metabolic hydrogen by inhibiting methanogenesis in the rumen simulation technique (RUSITEC). Frontiers in Microbiology 8: 393.

Haisan, J., Sun, Y., Guan, L.L., Beauchemin, K.A., Iwaasa, A., Duval, S., Barreda, D.R. and Oba, M. 2014. The effects of feeding 3-nitrooxypropanol on methane emissions and productivity of Holstein cows in mid lactation. Journal of Dairy Science 97: 3110-3119.

Haisan, J., Sun, Y., Guan, L., Beauchemin, K.A., Iwaasa, A., Duval, S., Kindermann, M., Barreda, D.R. and Oba, M. 2017. The effects of feeding 3-nitrooxypropanol at two doses on milk production, rumen fermentation, plasma metabolites, nutrient digestibility, and methane emissions in lactating Holstein cows. Animal Production Science 57: 282-289.

Hanrahan, J.P. 1999. Genetic and non-genetic factors affecting lamb growth and carcass quality. Teagasc End of Project Reports: Sheep Series No. 8. ISBN 1841700622.

Hanrahan, J.P. 2006. Observations on variation in weight and classification of carcasses from Irish lambs. Irish Grassland Association Journal 40: 8-14. 
Hanrahan, J.P. 2010. Technical efficiency in the sheep industry opportunities and potential. Irish Grassland Association Journal 44: 65-80.

Hanrahan, J.P. and Keady, T.W.J. 2013. Lamb mortality in a prolific flock managed in an intensive grassland system: effect of lamb factors. Advances in Animal Biosciences 4: 7.

Hanrahan, L., McHugh, N., Hennessy, T., Moran, B., Kearney, R., Wallace, M. and Shalloo, L. 2018. Factors associated with profitability in pasture-based systems of milk production. Journal of Dairy Science 101: 5474-5485.

Hargreaves, P.R., Sunkel, M. and Towers, E. 2019. Impact of Mootral Ruminant ${ }^{\oplus}$ on methane emissions and performance on dairy cows in real farm conditions. Proceedings XIIIth International Symposium on Ruminant Physiology, Leipzig, Germany, page 126.

Hennessy, D., Delaby, L., van den Pol-van Dasselaar, A. and Shalloo, L. 2020. Increasing grazing in dairy cow milk production systems in Europe. Sustainability 12: 2443.

Heslin, J., Kenny, D.A., Kelly, A.K. and McGee, M. 2020. Age at puberty and pregnancy rate in beef heifer genotypes offered contrasting nutrition levels from 8 to 13 months of age. Animal Reproduction Science 212: 106221.

Hession, D.V. 2021. Delevoping effective sheep mineral supplementation strategies in Ireland. PhD thesis, University of Nottingham, Nottingham, United Kingdom.

Hession, D.V., Hanrahan, K., Kendall, N.R., Moran, B. and Keady, T.W.J. 2018a. A survey of mineral supplementation and delivery strategies on Irish sheep farms. Advances in Animal Biosciences 9: 56.

Hession, D.V., Kendall, N.R., Hanrahan, J.P. and Keady, T.W.J. 2018b. A preliminary evaluation of the effects of supplementing ewes with Co, including method of administration, on ewe performance and that of their progeny. Advances in Animal Biosciences 9: 51.

Higgs, R.J., Sheahan, A.J., Mandok, K., Van Amburgh, M.E., and Roche, J.R. 2013. The effect of starch-, fiber-, or sugar-based supplements on nitrogen utilization in grazing dairy cows. Journal of Dairy Science 96: 3857-3866.

Horan, B., Mee, J.F., Rath, M., O'Connor, P. and Dillon, P. 2004. The effect of strain of Holstein-Friesian cow and feeding system on reproductive performance in seasonal-calving milk production systems. Animal Science 79: 453-467.

Horan, B., Dillon, P., Faverdin, P., Delaby, L., Buckley, F. and Rath, M. 2005. The interaction of strain of Holstein-Friesian cows and pasture-based feed systems on milk yield, body weight, and body condition score. Journal of Dairy Science 88: 1231-1243.

Hristov, A.N., Oh, J., Firkins, J.L., Dijkstra, J., Kebreab, E., Waghorn, G., Makkar, H.P.S., Adesogan, A.T., Yang, W., Lee, C., Gerber, P.J., Henderson, B. and Tricarico, J.M. 2013. Special topics - Mitigation of methane and nitrous oxide emissions from animal operations: I. A review of enteric methane mitigation options. Journal of Animal Science 91: 5045-5069.

Hristov, A.N., Oh, J., Giallongo, F., Frederick, T.W., Harper, M.T., Weeks, H.L., Branco, A.F., Moate, P.J., Deighton, M.H., Williams,
S.R.O. and Kindermann, M. 2015. An inhibitor persistently decreased enteric methane emission from dairy cows with no negative effect on milk production. Proceedings of the National Academy of Sciences 112: 10663-10668.

Huhtanen, P., Ahvenjarvi, S., Weisbjerg, M.R. and Norgaard, P. 2006. Digestion and passage of fibre in ruminants. In: "Ruminant Physiology: Digestion, Metabolism and Impact of Nutrition on Gene Expression, Immunology and Stress" (eds. K. Sejrsen, T. Hvelplund, and M.O. Nielsen), Wageningen Academic Publisher, Wageningen, The Netherlands, pages 87-135.

Huhtanen, P., Seppälä, A., Ots, M., Ahvenjärvi, S. and Rinne, M. 2008. In vitro gas production profiles to estimate extent and effective first-order rate of neutral detergent fiber digestion in the rumen. Journal of Animal Science 86: 651-659.

Huhtanen, P., Ahvenjärvi, S., Broderick, G.A., Reynal, S.M. and Shingfield, K.J. 2010. Quantifying ruminal digestion of organic matter and neutral detergent fiber using the omasal sampling technique in cattle - a meta-analysis. Journal of Dairy Science 93: 3203-3215.

Hurley, M., Lewis, E., Beecher, M., Garry, B., Fleming, C., Boland, T., and Hennessy, D. 2021. Dry matter intake and in vivo digestibility of grass-only and grass-white clover in individually housed sheep in spring, summer and autumn. Animals 11: 306.

Institut National de Recherche Agronomique. 2018. "Feeding System for Ruminants". Wageningen Academic Publishers, Wageningen, The Netherlands.

Jami, E., Israel, A., Kotser, A. and Mizrahi, I. 2013. Exploring the bovine rumen bacterial community from birth to adulthood. The ISME Journal 7: 1069-1079.

Jayanegara, A., Sarwono, K.A., Kondo, M., Matsui, H., Ridla, M., Laconi, E.B. and Nahrowi. 2018. Use of 3-nitrooxypropanol as feed additive for mitigating enteric methane emissions from ruminants: a meta-analysis. Italian Journal of Animal Science 17: 650-656.

Johnson, K.A. and Johnson, D.E. 1995. Methane emissions from cattle. Journal of Animal Science 73: 2483-2492.

Jones, D.I.H. and Hayward, M.V. 1975. The effect of pepsin pretreatment of herbage on the prediction of dry matter digestibility from solubility in fungal cellulase solutions. Journal of the Science of Food and Agriculture 26: 711-718.

Keady, T.W.J. 2005. Ensiled maize and whole crop wheat forages for beef and dairy cattle: effects on animal performance. In "Silage Production and Utilization" (eds. R.S. Park and M.D. Stronge), Wageningen Academic Publishers, Wageningen, The Netherlands, pages 65-82.

Keady, T.W.J. 2010. Finishing store lambs-the options and the facts. Irish Grassland Association Journal 44: 81-92.

Keady, T.W.J. and Hanrahan, J.P. 2007. Extended grazing its potentials and limitations. Journal of the Irish Grassland Association 41: 81-96.

Keady, T.W.J. and Hanrahan, J.P. 2009a. Effects of shearing at housing, grass silage feed value and extended grazing herbage allowance on ewe and subsequent lamb performance. Animal 3: 143-151. 
Keady, T.W.J. and Hanrahan, J.P. 2009b. The effects of allowance and frequency of allocation of deferred herbage, and grass silage feed value, when offered to ewes in mid gestation on ewe and lamb performance and subsequent herbage yield. Animal 3: 879-890.

Keady, T.W.J. and Hanrahan, J.P. 2010. An evaluation of the effect of grass silage and concentrate feed level on ewe and subsequent progeny performance and on potential concentrate sparing effect. Advances in Animal Biosciences 1: 38.

Keady, T.W.J. and Hanrahan, J.P. 2012. Effect of concentrate feed level and protein source on the performance of ewes in late pregnancy and the performance of their progeny. Advances in Animal Biosciences 3: 77.

Keady, T.W.J. and Hanrahan, J.P. 2013a. Lamb mortality in a prolific flock managed in an intensive grassland system: effect of ewe factors. Proceedings of the Research Forum, Tullamore, Ireland, page 86.

Keady, T.W.J. and Hanrahan, J.P. 2013b. Effects of silage from maize crops differing in maturity at harvest, grass silage feed value and concentrate feed level on performance of finishing lambs. Animal 7: 1088-1098.

Keady, T.W.J. and Hanrahan, J.P. 2015. Effects of shearing, forage type and feed value, concentrate feed level and protein concentration of housed finishing lambs. Journal of Animal Science 93: 306-318.

Keady, T.W.J. and Hanrahan, J.P. 2018. Plane of nutrition during the rearing phase for replacement ewes of four genotypes: II - effects on performance during first pregnancy and to weaning, and of their progeny. Animal 12: 722-732.

Keady, T.W.J. and Hanrahan, J.P. 2021. Effects of grass and maize silage feed value, offering soybean meal with maize silage, and concentrate feed level in late pregnancy, on ewe and lamb performance. Animal 15: 10068.

Keady, T.W.J., Mayne, C.S. and Kilpatrick, D.J. 2003. The effect of maturity of maize silage at harvest on the performance of lactating dairy cows offered three contrasting grass silages. Proceedings of the British Society of Animal Science, page 126.

Keady, T.W.J., Hanrahan, J.P. and Flanagan, S. 2007. The effects of extended grazing during mid, late and throughout pregnancy, and winter shearing indoors, on ewe performance and subsequent lamb growth rate. Irish Journal of Agricultural and Food Research 46: $169-180$.

Keady, T.W.J., Kilpatrick, D.J., Mayne, C.S. and Gordon, F.J. 2008a. Effects of replacing grass silage with maize silages, differing in maturity, on performance and potential concentrate sparing effect of dairy cows offered two feed value grass silages. Livestock Science 119: 1-11.

Keady, T.W.J., Lively, F.O, Kilpatrick, D.J., and Moss, B.W. 2008b. The effects of grain treatment, grain feed level, and grass silage feed value on the performance of, and meat quality from finishing beef cattle. Animal 2: 149-159.

Keady, T.W.J., Hanrahan, J.P. and Flanagan, S. 2009. An evaluation of two grassland based systems of mid-season prime lamb production using prolific ewes. Irish Journal of Agriculture and Food Research 48: 87-101.

Keady, T.W.J., Gordon, A.W. and Moss, B.W. 2013a. Effects of replacing grass silage with maize silages differing in inclusion level and maturity on the performance, meat quality and concentrate sparing effect of beef cattle. Animal 7: 768-777.

Keady, T.W.J., Hanrahan, J.P., Marley, C.L. and Scollan, N.D. 2013b. Silage production - factors affecting the utilization of ensiled forages by beef cattle, dairy cows, pregnant ewes and finishing lambs. A review. Agricultural and Food Science 22: 70-92.

Keady, T.W.J., Hanrahan, J.P., Campos, V., Allen, P. and Sweeney, T. 2015. The effects of castrating males on lamb performance and meat eating quality attributes Advances in Animal Biosciences 6: 130.

Keady, T.W.J., Hanrahan, J.P. and Fagan, S.P. 2017. Cobalt supplementation, alone or in combination with vitamin B12 and selenium: effects on lamb performance and mineral status. Journal of Animal Science 95: 379-386.

Keady, T.W.J., McNamara, N. and Hanrahan, J.P. 2018. Prime lamb production over 12 years of a rotational-grazing system - effect of birth and rearing type on lamb performance. Advances in Animal Biosciences 9: 57.

Keane, M.G. 2002. Response in weanlings to supplementary concentrates in winter and subsequent performance. Teagasc, Occasional series No. 4, Grange Research Centre, 36 pages.

Keane, M.G. 2005. Comparison of sugar-beet pulp and barley with and without soya bean meal as supplements to silage for growing steers. Irish Journal of Agricultural and Food Research 44: 15-26.

Keane, M.G. and Drennan, M.J. 2008. A comparison of Friesian, Aberdeen Angus $\times$ Friesian and Belgian Blue $\times$ Friesian steers finished at pasture or indoors. Livestock Science 115: 268-278.

Keane, M.G. and Moloney, A.P. 2009. A comparison of finishing systems and duration for spring-born Aberdeen Angus $\times$ HolsteinFriesian and Belgian Blue $\times$ Holstein-Friesian steers. Livestock Science 124: 223-232.

Keane, M.G., Drennan, M.J. and Moloney, A.P. 2006. Comparison of supplementary concentrate levels with grass silage, separate or total mixed ration feeding, and duration of finishing in beef steers. Livestock Science 103: 169-180.

Kelly, M., Moloney, A.P., Kelly, A. and McGee, M. 2018. Intake, growth, carcass and selected meat quality traits of steers offered grass silage and supplementary concentrates with increasing levels of dried corn gluten feed. Advances in Animal Biosciences 9: 150.

Kelly, P., Shalloo, L., Wallace, M. and Dillon, P. 2020. The Irish dairy industry - Recent history and strategy, current state and future challenges. International Journal of Dairy Technology 73: 309_ 323.

Kennedy, E., O'Donovan, M., Murphy, J.P., Delaby, L. and O'Mara, F. 2005. Effects of grass pasture and concentrate-based feeding systems for spring-calving dairy cows in early spring on performance during lactation. Grass and Forage Science 60: 310-318. 
Kennedy, E., Curran, J., Mayes, B., McEvoy, M., Murphy, J.P. and O'Donovan, M. 2011. Restricting dairy cow access time to pasture in early lactation: the effects on milk production, grazing behaviour and dry matter intake. Animal 5: 1805-1813.

Kennedy, R., Moloney, A.P., O'Riordan, E.G., Kelly, A. and McGee, M. 2021. Intake, growth and carcass traits of steers offered grass silage supplemented with barley- or oats-based rations with or without peas and beans. Animal-Science Proceedings 12: 1-145.

Kim, H., Lee, H.G., Baek, Y.C., Lee, S. and Seo, J. 2020. The effects of dietary supplementation with 3-nitrooxypropanol on enteric methane emissions, rumen fermentation, and production performance in ruminants: a meta-analysis. Journal of Animal Science and Technology 62: 31-42.

Kliem, K.E., Humphries, D.J., Kirton, P., Givens, D.I. and Reynolds, C.K., 2019. Differential effects of oilseed supplements on methane production and milk fatty acid concentrations in dairy cows. Animal 13: 309-317.

Kolver, E.S. 2003. Nutritional limitations to increased production on pasture-based systems. Proceedings of the Nutrition Society 62 : 291-300.

Kolver, E.S. and De Veth, M.J. 2002. Prediction of ruminal pH from pasture-based diets. Journal of Dairy Science 85: 1255-1266.

Kolver, E.S. and Muller, L.D. 1998. Performance and nutrient intake of high producing Holstein cows consuming pasture or a total mixed ration. Journal of Dairy Science 81: 1403-1411.

Krizsan, S., Mussadiq, Z., Hetta, M., Ramin, M., Nyholm, L., and Huhtanen, P. 2014. Predicting feeding value of forage maize hybrids harvested at different maturities and sites. Journal of Animal Feed Science 23: 269-278.

Laisse, S., Baumont, R., Dusart, L., Gaudré, D., Rouillé, B., Benoit, M.V.P., Rémond, D. and Peyraud, J. 2018. The net feed conversion efficiency of livestock: a new approach to assess the contribution of livestock to human feeding. INRA Products Animal 31: 269-287.

Läpple, D., Hennessy, T. and O'Donovan, M. 2012. Extended grazing: a detailed analysis of Irish dairy farms. Journal of Dairy Science 95: 188-195.

Lawrence, P., Kenny, D.A., Earley, B. and McGee, M. 2012. Grazed grass herbage intake and performance of beef heifers with predetermined phenotypic residual feed intake classification. Animal 6: 1648-1661.

Lawrence, P., Kenny, D.A., Earley, B. and McGee, M. 2013. Intake of conserved and grazed grass and performance traits in beef suckler cows differing in phenotypic residual feed intake. Livestock Science 152: 154-166.

Leahy, S., Clark, H. and Reisinger, A. 2020. Challenges and prospects for agricultural greenhouse gas mitigation pathways consistent with the Paris Agreement. Frontiers in Sustainable Food Systems 4: 69.

Lee, J.M., Matthew, C., Thom, E.R. and Chapman, D.F. 2012. Perennial ryegrass breeding in New Zealand: a dairy industry perspective. Crop and Pasture Science 63: 107-127.
Lenehan, C., Moloney, A.P., O'Riordan, E.G., Kelly, A. and McGee, M. 2015a. Finishing autumn-born bulls from pasture in the first half of the grazing season using concentrates. Proceedings of the Agricultural Research Forum, Tullamore, Ireland, page 39.

Lenehan, C., Moloney, A.P., O'Riordan, E.G., Kelly, A. and McGee, M. 2015b. Effect of substituting barley with maize on the performance of suckler-bred bulls offered a high concentrate diet. Proceedings of the Agricultural Research Forum, Tullamore, Ireland, page 82.

Lenehan, C., Moloney, A.P., O'Riordan, E.G., Kelly, A. and McGee, M. 2015c. Effects of supplementary concentrate type and protein level on growth of suckler-bred weanling bulls offered grass silage. Proceedings of the Agricultural Research Forum, Tullamore, Ireland, page 74 .

Lenehan, C., Moloney, A.P., O'Riordan, E.G., Kelly, A. and McGee, M. 2017a. Pasture-based finishing of early-maturing sired suckler beef bulls at 15 or 19 months of age. Advances in Animal Biosciences 8: s1, 28-32.

Lenehan, C., Moloney, A., O'Riordan, E.G., Kelly, A. and McGee, M. 2017b. Comparison of rolled barley with citrus pulp as a supplement for growing cattle offered grass silage. Advances in Animal Biosciences 8: s1, 33-37.

Lewis, E., Coughlan, F., O'Donovan, M. and Wims, C. 2010. The effect of grazing different pasture herbage masses on rumen $\mathrm{pH}$ in lactating dairy cows. Advances in Animal Biosciences 1: 293-293.

Lucy, M.C. 2001. Reproductive loss in high-producing dairy cattle: where will it end? Journal of Dairy Science 84: 1277-1293.

Lucy, M.C. 2019. Symposium review: Selection for fertility in the modern dairy cow—current status and future direction for genetic selection. Journal of Dairy Science 102: 3706-3721.

MacDonald, K.A., Beca, D., Penno, J.W., Lancaster, J.A.S., and Roche, J.R. 2011. Short communication: Effect of stocking rate on the economics of pasture-based dairy farms. Journal of Dairy Science. 94: 2581-2586

Machado, L., Magnusson, M., Paul, N.A., Kinley, R., de Nys, R. and Tomkins, N. 2016. Dose-response effects of Asparagopsis taxiformis and Oedogonium sp. on in vitro fermentation and methane production. Journal of Applied Phycology 28: 1443-1452.

Mambrini, M., and Peyraud, J.L. 1994. Mean retention time in digestive tract and digestion of fresh perennial ryegrass by lactating dairy cows: influence of grass maturity and comparison with maize silage diet. Reproduction Nutrition Development 34: 9-23.

Magee, D., Moloney, A.P., Kelly, A., O'Riordan, E.G. and McGee, M. 2015a. Replacement of barley with increasing levels of maize dried distillers' grains: intake, growth and carcass characteristics of beef cattle. Proceedings of the Agricultural Research Forum, Tullamore, Ireland, page 80.

Magee, D., Moloney, A.P., Kelly, A., O'Riordan, E.G. and McGee, M. 2015b. Intake and performance of beef cattle offered barleybased concentrates with increasing inclusion levels of soya hulls. Proceedings of the Agricultural Research Forum, Tullamore, Ireland, page 81. 
Magee, D., Moloney, A.P., Kelly, A., O'Riordan, E.G. and McGee, M. 2016. Inclusion of palm kernel expeller meal in barley-based concentrates for beef cattle. Book of Abstracts, 67th Annual Meeting of European Federation for Animal Science (EAAP), Belfast UK, page 669.

Marren, D., McGee, M., Moloney, A.P., Kelly, A. and O'Riordan, E.G. 2013. Effect of growth rate during the first indoor winter on performance to slaughter of late-maturing weaned suckler bred bulls. Proceedings of the Agricultural Research Forum, Tullamore, Ireland, page 34.

Marren, D., McGee, M., Moloney, A.P., Kelly, A.K., Vilaseca, M. and O'Riordan, E.G. 2015. Concentrate supplementation of grazing suckler bulls: effects on growth, carcass and meat quality characteristics. Proceedings of the Agricultural Research Forum, Tullamore, Ireland, page 40.

Martínez-Fernández, G., Abecia, L., Arco, A., Cantalapiedra-Hijar, G., Martín-García, A.I., Molina-Alcaide, E., Kindermann, M., Duval, S. and Yáñez-Ruiz, D.R. 2014. Effects of ethyl-3-nitrooxy propionate and 3-nitrooxypropanol on ruminal fermentation, microbial abundance, and methane emissions in sheep. Journal of Dairy Science 97: 3790-3799.

Martinez Fernandez, G., Duval, S.M., Kindermann, M., Schirra, H.J., Denman, S.E. and McSweeney, C.S. 2018. 3-NOP vs halogenated compound: methane production, ruminal fermentation and microbial community response in forage fed cattle. Frontiers in Microbiology 9: 1582.

McCabe, S., McHugh, N. and Prendiville, R. 2017. Evaluation of production efficiencies among primiparous suckler cows of diverse genetic index at pasture. Advances in Animal Bioscience 8: s55-s59.

McCabe, S., McHugh, N., O'Connell, N.E. and Prendiville, R. 2019. Comparative grazing behaviour of lactating suckler cows of contrasting genetic merit and genotype. Livestock Science 220: 129-136.

McCarthy, S., Horan, B., Rath, M., Linnane, M., O'Connor, P. and Dillon, P. 2007. The influence of strain of Holstein-Friesian dairy cow and pasture-based feeding system on grazing behaviour, intake and milk production. Grass and Forage Science 62: 13-26.

McCarthy, B., Delaby, L., Pierce, K.M., Journot, F., and Horan, B. 2010. Meta-analysis of the impact of stocking rate on the productivity of pasture-based milk production systems. Animal 5: 784-794.

McCarthy, K., McAloon, C., Lynch, M., Pierce, K. and Mulligan, F.J. 2020. Herb species inclusion in grazing swards for dairy cows-a systematic review and meta-analysis. Journal of Dairy Science 103: $1416-1430$

McEvoy, M., Kennedy, E., Murphy, J.P., Boland, T.M., Delaby, L. and O'Donovan, M. 2008. The effect of herbage allowance and concentrate supplementation on milk production performance and dry matter intake of spring-calving dairy cows in early lactation. Journal of Dairy Science 91: 1258-1269.

McGee, M. 2005. Recent developments in feeding beef cattle on grass silage-based diets. In: "Silage Production and Utilisation" (eds. R.S. Park and M.D. Stronge). Proceedings of the XIVth International Silage Conference, Wageningen Academic Publishers, Wageningen, The Netherlands, pages 51-64.

McGee, M. 2015. Feed efficiency in beef finishing systems. Irish Grassland Association Journal 49: 97-105.

McGee, M. and Earley, B. 2013. Effect of nutritional restriction in late pregnancy on performance of suckler cows and birth weight and passive immune status of their calves. Proceedings of the Agricultural Research Forum, Tullamore, Ireland, page 37.

McGee, M., Drennan, M.J. and Caffrey, P.J. 1996. Creep concentrates for suckled calves at pasture. Proceedings of the Agricultural Research Forum, UCD, Belfield Dublin, pages 51-52.

McGee, M., Drennan, M.J. and Caffrey, P.J. 1998. The effect of post-partum supplementation on the performance of primiparous suckler cows and their progeny. Irish Journal of Agriculture and Food Research 37: 117.

McGee, M., Drennan, M.J. and Caffrey, P.J. 2005. Effect of suckler cow genotype on energy requirements and performance in winter and subsequently at pasture. Irish Journal of Agricultural and Food Research 44: 157-171.

McGee, M., Drennan, M.J., and Crosson, P. 2014. Effect of concentrate feeding level in winter and turnout date to pasture in spring on biological and economic performance of weanling cattle in suckler beef production systems. Irish Journal of Agricultural and Food Research 53: 1-19.

McGee, M., O'Riordan, E., Kenny, D. and Moloney, A. 2018a. Beefcattle production: feed-efficiency. Veterinary Ireland Journal 8: 239-242.

McGee, M., Kelly, M., Kelly, M. and Moloney, A.P. 2018b. Comparison of rolled barley and oats as supplements to grass silage for finishing beef cattle. Advances in Animal Biosciences 9: 226.

McKay, Z.C., Lynch, M.B., Mulligan, F.J., Rajauria, G., Miller, C. and Pierce, K.M. 2019. The effect of concentrate supplementation type on milk production, dry matter intake, rumen fermentation, and nitrogen excretion in late-lactation, spring-calving grazing dairy cows. Journal of Dairy Science 102: 5042-5053.

McNamara, S., O'Mara, F.P., Rath, M. and Murphy, J.J. 2003. Effects of different transition diets on dry matter intake, milk production, and milk composition in dairy cows. Journal of Dairy Science $\mathbf{8 6}$ : 2397-2408.

McNamee, A., O'Riordan, E.G. and McGee, M. 2012. Effects of supplementary concentrates when grazing in autumn on performance of dairy crossbred steers finished at pasture or indoors. Proceeding of the Agricultural Research Forum, Tullamore, Ireland, page 86.

Meale, S.J., Popova, M., Saro, C., Martin, C., Bernard, A., Lagree, M., Yáñez-Ruiz, D.R., Boudra, H., Duval, S. and Morgavi, D.P. 2021. Early life dietary intervention in dairy calves results in a long-term reduction in methane emissions. Scientific Reports 11: 3003.

Mee, J.F. 2004. Temporal trends in reproductive performance in Irish dairy herds and associated risk factors. Irish Veterinary Journal 57: 158-166. 
Minchin, W. and McGee, M. 2011. Pre-partum intake and performance of beef suckler cow breed types and pre-weaning growth of their calves. Proceeding of the Agricultural Research Forum, Tullamore Ireland, page 50.

Minchin, W., O'Riordan, E.G. and McGee, M. 2011. Effect of postgrazing sward height on performance of beef suckler cows and growth of their calves during the grazing season. Proceeding of the Agricultural Research Forum, Tullamore Ireland, page 92.

Moore, S.G., Fair, T., Lonergan, P. and Butler, S.T. 2014. Genetic merit for fertility traits in Holstein cows: IV. Transition period, uterine health, and resumption of cyclicity. Journal of Dairy Science 97: 2740-2752.

Moran, B., Cummins, S.B., Creevey, C.J. and Butler, S.T. 2016. Transcriptomics of liver and muscle in Holstein cows genetically divergent for fertility highlight differences in nutrient partitioning and inflammation processes. BMC Genomics 17: 1-11.

Morgan, D.J. and Stakelum, G. 1987. The prediction of the digestibility of herbage for dairy cows. Irish Journal of Agricultural and Food Research 26: 23-34.

Morgan, D.J., Stakelum, G., and Dwyer, J. 1989. Modified neutral detergent cellulase digestibility procedure for use with the 'fibertec' system. Irish Journal of Agricultural and Food Research 28: 91-92.

Morrison, S.J. and Patterson, D.C. 2007. The effects of offering a range of forage and concentrate supplements on milk production and dry matter intake of grazing dairy cows. Grass and Forage Science 62: 332-345.

Muetzel, S., Lowe, K., Janssen, P.H., Pacheco, D., Bird, N., Walker, N., Vidoni, O., Schweikert, L., Clasadonte, L. and Kindermann, M. 2019. Towards the application of 3-nitrooxypropanol in pastoral farming systems. Proceedings of the 7th GGAA - Greenhouse Gas and Animal Agriculture Conference (Iguassu Falls), page 81.

Mulligan, F.J., O'Grady, L., Rice, D.A. and Doherty, M.L. 2006. A herd health approach to dairy cow nutrition and production diseases of the transition cow. Animal Reproduction Science 96: 331-353.

Murphy, J.J. 1999. Effect of dry period protein feeding on post-partum milk production and composition. Livestock Production Science 57: 169-179.

Murphy, D. 2020. Optimisation of grass measurement technologies through field experimentation and numerical simulation methods. $\mathrm{PhD}$ thesis, Department of Process, Energy and Transport Engineering, Cork Institute of Technology, Cork, Ireland.

Murphy, B.M., Drennan, M.J., O'Mara, F.P. and McGee, M. 2008. Performance and feed intake of five beef suckler cow genotypes and pre-weaning growth of their progeny. Irish Journal of Agricultural and Food Research 47: 13-25.

National Farm Survey. 2019. Mid-season Lowland Lamb Enterprise Factsheet. Teagasc, Carlow, Ireland. Available online: https:// www.teagasc.ie/news--events/daily/sheep/teagasc-national-farmsurvey-2019-mid-season-lowland-lamb-enterprise-factsheet.php [Accessed 4 November 2021].
Nousiainen, J. 2004. Development of tools for the nutritional management of dairy cows on silage-based diets. PhD thesis, Helsinki University, Helsinki, Finland.

Nousiainen, J., Ahvenjärvi, S., Rinne, M., Hellämäki, M. and Huhtanen, P. 2004. Prediction of indigestible cell wall fraction of grass silage by near infrared reflectance spectroscopy. Animal Feed Science Technology 115: 295-311.

Noziere, P., Sauvant, D. and Delaby, L. 2018. "INRA Feeding System for Ruminants". Wageningen Academic Publishers. Available online: https://doi.org/10.3920/978-90-8686-292-4.

Oba, M. and Allen, M.S. 1999. Evaluation of the importance of the digestibility of neutral detergent fiber from forage: effects on dry matter intake and milk yield of dairy cows. Journal of Dairy Science 82: 589-596.

O'Brien, D., Shalloo, L., Patton, J., Buckley, F., Grainger, C. and Wallace, M. 2012. Evaluation of the effect of accounting method, IPCC v. LCA, on grass-based and confinement dairy systems' greenhouse gas emissions. Animal 6: 1512-1527.

O'Callaghan, T.F., Hennessy, D., McAuliffe, S., Kilcawley, K.N., O'Donovan, M., Dillon, P., Ross, R.P., and Stanton, S. 2016. Effect of pasture versus indoor feeding systems on raw milk composition and quality over an entire lactation. Journal of Dairy Science 99: 9424-9440.

O'Connor, A., Moloney, A., O'Kiely, P., Boland, T. and McGee, M. 2018. Intake, digestion and nitrogen balance in beef cattle offered grass herbage supplemented with citrus pulp. Journal of Animal Science 96(suppl 3): 409-410.

O'Connor, A., Moloney, A.P., O'Kiely, P., Boland, T. and McGee, M. 2019. Effects of fertiliser nitrogen rate to spring grass on apparent digestibility, nitrogen balance, ruminal fermentation and microbial nitrogen production in beef cattle and in vitro rumen fermentation and methane output. Animal Feed Science and Technology 254(2019): 114198.

O'Donovan, M., Dillon, P., Rath, M. and Stakelum, G. 2002. A comparison of four methods of herbage mass estimation. Irish Journal of Agricultural and Food Research 41: 17-27.

O'Donovan, M., Lewis, E. and O'Kiely, P. 2011 Requirements of future grass-based ruminant production systems in Ireland. Irish Journal of Agricultural and Food Research 50: 1-21.

O'Grady, L., Doherty, M.L. and Mulligan, F.J. 2008. Subacute ruminal acidosis (SARA) in grazing Irish dairy cows. The Veterinary Journal 176: 44-49.

O'Hara, E., Kenny, D.A., McGovern, E., Byrne, C.J., McCabe, M.S., Guan, L.L. and Waters, S.M. 2020. Investigating temporal microbial dynamics in the rumen of beef calves raised on two farms during early life. FEMS Microbiology Ecology 96: fiz203.

O'Kiely, P. 2015. Grass silage in Ireland - developments and future needs. Irish Grassland Association Journal 30: 16-20.

O'Mara, F.P. 2000. "A Net Energy System for Cattle and Sheep. Version 1.2". University College Dublin, Ireland.

O'Mara, F.P., Stakelum, G.K., Dillon, P., Murphy, J.J. and Rath, M. 1997. Rumen fermentation and nutrient flows for cows fed grass 
and grass supplemented with molassed beet pulp pellets. Journal of Dairy Science 80: 2466-2474.

O'Neill, B.F., Deighton, M.H., O'Loughlin, B.M., Mulligan, F.J., Boland, T.M., O'Donovan, M. and Lewis, E. 2011. Effects of a perennial ryegrass diet or total mixed ration diet offered to spring-calving Holstein-Friesian dairy cows on methane emissions, dry matter intake, and milk production. Journal of Dairy Science 94: 1941-1951.

O'Riordan, E.G., Keane, M.G. and McGee, M. 2011a. Effects of turnout date to pasture in spring and post-grazing sward height on performance of dairy crossbred steers during the grazing season. Proceeding of the Agricultural Research Forum, Tullamore, Ireland, page 86.

O'Riordan, E.G., Crosson, P. and McGee, M. 2011b. Finishing male cattle from the beef suckler herd. Irish Grassland Association Journal 45: 131-132.

Owens, D., McGee, M. and Boland, T. 2008a. Effect of grass regrowth interval on intake, rumen digestion and nutrient flow to the omasum in beef cattle. Animal Feed Science and Technology 146: 21-41.

Owens, D., McGee, M. and Boland, T. 2008b. Intake, rumen fermentation, degradability and digestion kinetics in beef cattle offered autumn grass herbage differing in regrowth interval. Grass and Forage Science 63: 369-379.

Owens, D., McGee, M., Boland, T. and O'Kiely, P. 2008c. Intake, rumen fermentation and nutrient flow to the omasum in beef cattle fed grass silage fortified with sucrose and/or supplemented with concentrate. Animal Feed Science and Technology 144: 23-43.

Patton, D., Shalloo, L., Pierce, K.M. and Horan, B., 2012. A biological and economic comparison of 2 pasture-based production systems on a wetland drumlin soil in the northern region of Ireland. Journal of Dairy Science 95: 484-495.

Peyraud, J.L. 1993. Comparaison de la digestion du trèfle blanc et des graminées prairiales chez la vache laitière. Fourrages 135: 465-473.

Peyraud, J.L. 2017. The role of grassland based production system for sustainable protein production. Proceedings of the Annual Meeting of the Brazilian Society of Animal Science, pages 243-255.

Peyraud, J.L. and Delagarde, R. 2013. Managing variations in dairy cow nutrient supply under grazing. Animal 7: 57-67.

Peyraud, J., Astigarraga, L. and Faverdin, P. 1997. Digestion of fresh perennial ryegrass fertilized at two levels of nitrogen by lactating dairy cows. Animal Feed Science Technology 64: 155-171.

Phelan, P., Moloney, A.P., McGeough, E.J., Humphreys, J., Bertilsson, J., O'Riordan, E.G. and O'Kiely, P. 2015. Forage legumes for grazing and conserving in ruminant production systems. Critical Reviews in Plant Sciences 34: 281-326.

Pullanagari, R.R, Yule, I., Tuohy, M.P., Hedley, M.J., Dynes, R.A., King, W.M., Tuohy, M.P., Hedley, M.J., Dynes, R.A. and King, W.M. 2012. In-field hyperspectral proximal sensing for estimating quality parameters of mixed pasture. Precision Agriculture 13: 351-369.
Raffrenato, E., Ross, D.A. and Van Amburgh, M.E. 2018. Development of an in vitro method to determine rumen undigested aNDFom for use in feed evaluation. Journal of Dairy Science 101: 9888-9900.

Ramsbottom, G., Horan, B., Berry, D.P. and Roche, J.R. 2015. Factors associated with the financial performance of spring-calving, pasturebased dairy farms. Journal of Dairy Science 98: 3526-3540.

Reid, M., O'Donovan, M., Elliott, C.T., Bailey, J.S., Watson, C.J., Lalor, S.T.J., Corrigan, B., Fenelon, M.A. and Lewis, E. 2015. The effect of dietary crude protein and phosphorus on grass-fed dairy cow production, nutrient status, and milk heat stability. Journal of Dairy Science 98: 517-531.

Regan, M., Lenehan, C., Moloney, A.P., O'Riordan, E.G., Kelly, A.K. and McGee, M. 2018. Finishing late-maturing suckler steers and bulls from pasture: effect of concentrate supplementation. Grassland Science in Europe 23: 485-487.

Ring, S.C., Evans, R.D., Cromie, A.R. and Berry, D.P. 2021. Crosssectional analyses of a national database to determine if superior genetic merit translates to superior dairy cow performance. Journal of Dairy Science. 104: 8076-8093.

Rius, A., Kittelmann, S., Macdonald, K., Waghorn, G., Janssen, P. and Sikkema, E. 2012. Nitrogen metabolism and rumen microbial enumeration in lactating cows with divergent residual feed intake fed high-digestibility pasture. Journal of Dairy Science 95 : 5024-5034.

Roche, J.R., Friggens, N.C., Kay, J.K., Fisher, M.W., Stafford, K.J. and Berry, D.P. 2009a. Invited review: Body condition score and its association with dairy cow productivity, health, and welfare. Journal of Dairy Science 92: 5769-5801.

Roche, J., Turner, L., Lee, J., Edmeades, D., Donaghy, D., Macdonald, K., Penno, J. and Berry, D. 2009b. Weather, herbage quality and milk production in pastoral systems. 2. Temporal patterns and intra-relationships in herbage quality and mineral concentration parameters. Animal Production Science 49: 200-210.

Romero-Perez, A., Okine, E.K., McGinn, S.M., Guan, L.L., Oba, M., Duval, S.M., Kindermann, M. and Beauchemin, K.A. 2014 The potential of 3-nitrooxypropanol to lower enteric methane emissions from beef cattle. Journal of Animal Science 92: 4682-4693.

Roque, B.M., Van Lingen, H.J., Vrancken, H. and Kebreab, E. 2019a. Effect of Mootral-a garlic-and citrus-extract-based feed additive-on enteric methane emissions in feedlot cattle. Translational Animal Science 3: 1383-1388.

Roque, B.M., Salwen, J.K., Kinley, R. and Kebreab, E. 2019b. Inclusion of Asparagopsis armata in lactating dairy cows' diet reduces enteric methane emission by over 50 percent. Journal of Cleaner Production 234: 132-138.

Ruelle, E., Shalloo, L., Wallace, M. and Delaby, L. 2015. Development and evaluation of the pasture-based herd dynamic milk (PBHDM) model for dairy systems. European Journal of Agronomy 71: 106-114.

Russell, J.B. and Martin, S.A. 1984. Effects of various methane inhibitors on the fermentation of amino acids by mixed rumen 
microorganisms in vitro. Journal of Animal Science 59: 13291338.

Ryan, G., Murphy, J.J., Crosse, S. and Rath, M. 2003. The effect of pre-calving diet on post-calving cow performance. Livestock Production Science 79: 61-71.

Ryan, W., Hennessy, D., Boland, T.M. and Shalloo, L. 2012. The effect of grazing season length on nitrogen utilization efficiency and nitrogen balance in spring-calving dairy production systems. The Journal of Agricultural Science 150: 630-643

Sapkota, D., Kelly, A.K., Crosson, P., White, R.R. and McGee, M. 2020. Quantification of cow milk yield and pre-weaning calf growth response in temperate pasture-based beef suckler systems: a meta-analysis. Livestock Science 241: 104222.

Schroeder, G.F., Gagliostro, G.A., Bargo, F., Delahoy, J.E. and Muller, L.D. 2004. Effects of fat supplementation on milk production and composition by dairy cows on pasture: a review. Livestock Production Science 86: 1-18.

Shalloo, L., Dillon, P., Rath, M. and Wallace, M. 2004. Description and validation of the Moorepark dairy system model. Journal of Dairy Science 87: 1945-1959.

Shalloo, L., Cromie, A. and McHugh, N. 2014. Effect of fertility on the economics of pasture-based dairy systems. Animal 8: 222-231.

Sidali, K.L., Spiller, A. and von Meyer-Hofer, M. 2016. Consumer expectations regarding sustainable food: Insights from developed and emerging markets. International Food and Agribusiness Management Review 19: 141-170.

Smit, H., Tas, B., Taweel, H., Tamminga, S., and Elgersma, A. 2005. Effects of perennial ryegrass (Lolium perenne L.) cultivars on herbage production, nutritional quality and herbage intake of grazing dairy cows. Grass and Forage Science 60: 297-309.

Stakelum, G. and Dillon, P. 2003. The effect of supplement type on the rumen fermentation pattern of cows fed fresh grass and the in-sacco disappearance of grass in the rumen. Irish Journal of Agricultural and Food Research 42: 213-228.

Stakelum, G. and Dillon, P. 2007. The effect of grazing pressure on rotationally grazed pastures in spring/early summer on the performance of dairy cows in the summer/autumn period. Irish Journal of Agricultural and Food Research 46: 29-46.

Stakelum, G., Morgan, D. and Dillon, P. 1988. A comparison of in vitro procedures for estimating herbage digestibility. Irish Journal of Agricultural and Food Research 27: 104-105.

Steen, R.W.J. 1984. The effects of wilting and mechanical treatment of grass prior to ensiling on the performance of beef cattle and beef output per hectare. In: "Fifty-Seventh Annual Report of the Agricultural Research Institute of Northern Ireland", pages 21-32.

Steen, R.W.J., Kilpatrick, D.J. and Porter, M.G. 2002. Effects of the proportions of high or medium digestibility grass silage and concentrates in the diets of beef cattle on ADG, carcass composition and fatty acid composition of muscle. Grass and Forage Science 57: 279-291.
Taylor, R.F., Crosson, P., Kelly, A.K. and McGee, M. 2018. Benchmarking technical and economic performance of beef cowcalf to finishing production systems in Ireland. The Professional Animal Scientist 34: 421-434.

Taylor, R.F., McGee, M., Kelly, A.K. and Crosson, P. 2020. Bioeconomic and greenhouse gas emissions modelling of the factors influencing technical efficiency of temperate grassland-based suckler calf-to-beef production systems. Agricultural Systems 183: 102860.

Teagasc. 2019. National Farm Survey 2019 Results. Available online: https://www.teagasc.ie/media/website/publications/2020/ Teagasc-National-Farm-Survey-2019.pdf.

Tilley, J.M.A. and Terry, R.A. 1963. A two stage technique for in vitro digestion of forage crops. Journal of the British Grassland Society 18: 104-111.

Udén, P. 2006. Recovery of insoluble fiber fractions by filtration and centrifugation. Animal Feed Science and Technology 129: 316-328.

Vance, E.R., Ferris, C.P., Elliott, C.T., Hartley, H.M. and Kilpatrick, D.J. 2013. Comparison of the performance of Holstein-Friesian and Jersey $\times$ Holstein-Friesian crossbred dairy cows within three contrasting grassland-based systems of milk production. Livestock Science 151: 66-79.

Van Gastelen, S., Dijkstra, J. and Bannink, A. 2019. Are dietary strategies to mitigate enteric methane emission equally effective across dairy cattle, beef cattle, and sheep? Journal of Dairy Science 102: 6109-6130.

Van Soest, P.J. 1994. "Nutritional Ecology of the Ruminant", 2nd Edition, Cornell University Press, Ithaca, NY.

Van Soest, P.J., Mertens, D.R. and Denium, B. 1978. Pre-harvest factors influencing quality of conserved forages. Journal of Animal Science 47: 712-720.

Vyas, D., McGinn, S.M., Duval, S.M., Kindermann, M. and Beauchemin, K.A. 2016. Effects of sustained reduction of enteric methane emissions with dietary supplementation of 3-nitrooxypropanol on growth performance of growing and finishing beef cattle. Journal of Animal Science 94: 2024-2034.

Vyas D, McGinn, S.M., Duval, S., Kindermann, M. and Beauchemin, K.A. 2018a. The combined effects of supplementing monensin and 3-nitrooxypropanol on methane emissions, growth rate, and feed conversion efficiency in beef cattle fed high-forage and highgrain diets. Journal of Animal Science 96: 2923-2938.

Vyas, D., McGinn, S.M., Duval, S.M., Kindermann, M.K. and Beauchemin, K.A. 2018b. Optimal dose of 3-nitrooxypropanol for decreasing enteric methane emissions from beef cattle fed high-forage and high-grain diets. Animal Production Science 58 : 1049-1055.

Whelan, S.J., Pierce, K.M., Flynn, B. and Mulligan, F.J. 2012a. Effect of supplemental concentrate type on milk production and metabolic status in early-lactation dairy cows grazing perennial ryegrass-based pasture. Journal of Dairy Science 95: 4541-4549.

Whelan, S.J., Pierce, K.M., McCarney, C., Flynn, B. and Mulligan, F.J. 2012b. Effect of supplementary concentrate type on nitrogen 
partitioning in early lactation dairy cows offered perennial ryegrassbased pasture. Journal of Dairy Science 95: 4468-4477.

Younge, B., Murphy, J., and Rath, M. 2004. Nutrient metabolism in the rumen and milk production in cows fed on grass-silage and fresh grass based diets. Livestock Production Science 88: 43-54.
Zontini, A., Foskolos, A., Ross, D.A., Metcalf, J., Doane, P.H. and Van Amburgh, M.E. 2015. Formulating diets for lactating cattle using multiple pools of NDF digestibility. Proceedings of the Cornell Nutrition Conference, Syracuse, NY. Cornell University, Ithaca, NY, pages 189-196. 